\title{
Life cycle assessment of rail freight transport in Belgium
}

\author{
Angel L. Merchan ${ }^{1}$ (i) $\cdot$ Sandra Belboom ${ }^{1} \cdot$ Angélique Léonard $^{1}$
}

Received: 16 November 2019 / Accepted: 20 April 2020

(c) Springer-Verlag GmbH Germany, part of Springer Nature 2020

\begin{abstract}
The objective of this paper is to determine the environmental impact of rail freight transport in Belgium using the life cycle assessment (LCA) methodology. The study includes the assessment of diesel trains, electric trains and rail freight transport considering the Belgian traction mix. Moreover, a comparison of the environmental impacts of electric trains using the electricity supply mix of different European countries has been performed. The rail freight transport system has been divided into three sub-systems: rail transport operation, rail equipment and rail infrastructure. The system approach of the LCA methodology involves studying both the direct processes connected with the transport activity (e.g. energy consumption or direct emissions), as well as other necessary elements for rail transport such as energy production, rolling stock and railway infrastructure. A comprehensive study of the Belgian railway network has been performed, collecting country-specific data on the construction, maintenance and disposal of infrastructure. Electric trains present a better environmental performance than diesel trains in Belgium. For example, the use of electric trains (using the Belgian electricity supply mix of 2012) rather than diesel trains represents a reduction of $26 \%$ of environmental impact on climate change. The electricity supply mix contributes significantly to the environmental performance of electric trains. As the use of electric trains increases in future, the energy split for the electricity generation will be more important in the environmental impacts of goods transport. The increased use of electric trains represents an opportunity to attain a more environmentally and energy-efficient rail freight transport system, especially when they are powered by sustainable electricity.
\end{abstract}

\section{Graphic abstract}

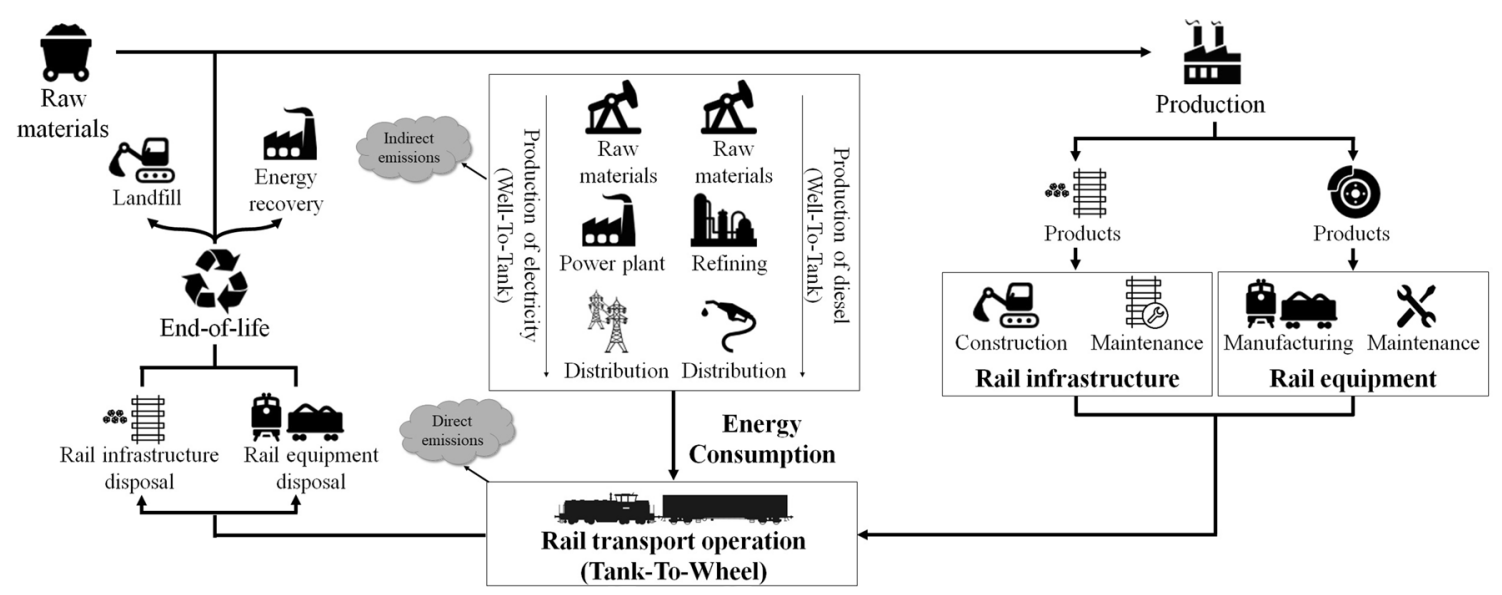

Keywords Life cycle assessment $\cdot$ Rail freight transport · Railway infrastructure $\cdot$ Electricity supply mix

Angel L. Merchan

a.merchan@uliege.be

1 Chemical Engineering, PEPs Group- Products, Environment and Processes, University of Liège, Bat. B6 Quartier Agora Allée du six Août 11, 4000 Liège, Belgium 


\section{Introduction}

Many public authorities are adopting initiatives to enhance the sustainability of freight transport. For instance, the European Commission defined strategic goals in its 2011 White Paper on transport (European Commission 2011) aiming at the development of rail freight transport in Europe. In the year 2012, road transport was the predominant mode in the European inland freight transport. Thereby, $75.3 \%$ of the total inland freight expressed in tonne-kilometres (tkm) in the European Union (EU-28) were transported by road, $18.1 \%$ by rail and $6.7 \%$ by inland waterways. Regarding the modal split of Belgium, road transport accounted for $64.5 \%$, rail for $18.1 \%$ and inland waterways for $20.9 \%$ of the total inland freight transport in 2012 (Eurostat statistics 2017). Rail freight transport experiences strong competition from inland waterways transport to attract the goods moved by road transport in Belgium. However, in the EU-28 the competition between these transport modes is lower since inland waterways transport is very restricted to certain geographic areas.

Transport of both passengers and goods is essential for economic and social development. However, transport also has harmful effects on the environment. In recent years, climate change is considered as one of the most important environmental problems by the society. In 2012, $24.2 \%$ and $34.3 \%$ of the total greenhouse gas (GHG) emissions were produced by the transport sector in the European Union (EU-28) and Belgium, respectively (Eurostat Statistics 2017). If we analyse which transport modes contributed most to the GHG emissions in 2012, road transport accounts for $17.4 \%$ in the EU-28 and $17 \%$ in Belgium, whilst rail transport represents a small share of the total GHG emissions, accounting for $0.37 \%$ in the EU-28 and $0.29 \%$ in Belgium. Note that the international navigation was responsible for $13.9 \%$ of the total GHG emissions due to the dynamic port activity in Belgium, including the Port of Antwerp, one of the largest ports in Europe (Merchan et al. 2019).

Moreover, the pollutants emitted by transport have a negative impact in the human health. Thereby, population exposure to poor air quality and especially to some harmful air pollutants such as particulate matter, nitrogen oxides $\left(\mathrm{NO}_{\mathrm{X}}\right)$ and tropospheric ozone remains a considerable environmental health issue for cities. Transport is the main source of $\mathrm{NO}_{\mathrm{X}}$, which is in turn a precursor to tropospheric ozone. For $\mathrm{NO}_{\mathrm{X}}$, road transport was responsible for $38.1 \%$ in the EU-28 and $48.3 \%$ in Belgium of the total emissions in 2012, accounting for $7.3 \%$ and $5.6 \%$ the other transport modes in the EU-28 and Belgium, respectively (Eurostat Statistics 2017). Furthermore, transport is a major source of other pollutants such as primary particulate matter $\left(\mathrm{PM}_{2.5}\right)$, non-methane volatile organic compounds (NMVOCs), sulphur dioxide $\left(\mathrm{SO}_{2}\right)$ or carbon monoxide (CO). Focusing on rail transport, these pollutant emissions can be direct or indirect depending on whether diesel or electric trains are used. Therefore, the use of electric trains rather than diesel trains could lead to a reduction in local air pollution, since indirect emissions due to the electricity generation are not produced in densely populated areas. Furthermore, other particulate emissions are produced from the wear between the brake-wheel and wheel-rail interfaces during the rail transport activity.

Additionally, transport is the sector with the highest energy consumption in the EU-28 and the second in Belgium with a $31.7 \%$ and $28.3 \%$ of the final energy consumption in the year 2012, respectively. Within transport sector, road transport constitutes $81.6 \%$ in the EU-28 and $82.4 \%$ in Belgium of the transport final energy consumption (Eurostat statistics 2017). The large amount of energy consumed by transport, together with the use of other resources such as land and raw materials for the transport infrastructures and vehicles, could lead to problems of resource scarcity.

In the light of these observations, the shifting of road freight transport in long distances to rail freight transport is an opportunity to enhance the transport of goods in the environmental, social and economic aspects. Nevertheless, among other factors, including the high operational costs of rail freight transport and the competition with passenger trains, the characteristics of the railway infrastructure could hamper the development of rail freight transport in Europe. Thereby, the smaller length of the railway network compared to the road network produces the mass use of the railway infrastructure and therefore causes poor flexibility of the rail freight market. Moreover, the lack of intermodal terminals results in a weak access to the railway network and thus the lack of direct links of the rail freight market. Finally, the lack of interoperability between railway networks of different countries as a consequence of the lack of standardisation in Europe of the railway infrastructure causes difficulties in the rail freight transport in long distances (Troch et al. 2017). Considering the above, the growth in rail freight transport promoted by the European authorities presents a number of major challenges that may involve the need to expand the railway network, leading to a chain of environmental consequences that should be studied. The enhancement of the railway infrastructure to improve the flexibility of rail transport, the construction of intermodal terminals to facilitate the intermodal transport and the improvement in the interoperability between countries (acting on the infrastructure, signalling, traffic management and rolling stock for example) would encourage companies to use rail freight transport and therefore stimulating a modal shift from road to rail transport (Gleave et al. 2015). 
In this framework, the life cycle assessment (LCA) methodology is a suitable method for determining the environmental impact of rail freight transport and finding ways to enhance its sustainability. The advantage of using the LCA methodology is that it involves studying both the direct processes connected with the transport activity (e.g. energy consumption or direct emissions), as well as other necessary elements for rail transport such as energy production (electricity and diesel in this study), rail equipment and railway infrastructure.

The LCA methodology applied to transport has been investigated in several transport studies, either passengers or goods and in different transport modes such as road, rail, inland waterways and air transport. However, no LCA study has focused on the environmental impact of rail freight transport in Belgium. Among the most important contributions, let us mention: Spielmann and Scholz (2005), Facanha and Horvath (2006, 2007), Chester and Horvath (2009), Spielmann et al. (2007), Stripple and Uppenberg (2010) and Fries and Hellweg (2014). Furthermore, it should be mentioned some articles that have analysed the environmental impact of high-speed rail from a life cycle perspective: Von Rozycki et al. (2003), Chester and Horvath (2010), Yue et al. (2015), Jones et al. (2017), Bueno et al. (2017), Bilgili et al. (2019), Lin et al. (2019) and De Bortoli et al. (2020).

Spielmann and Scholz (2005) analysed the environmental life cycle performance of rail, inland waterways and road transport in Europe, concluding that for gaseous emissions rail or inland waterways transport presented $92 \%$ and $65 \%$ less gaseous emissions compared to road transport, respectively. Moreover, they did a comparison of the LCA of rail transport in Switzerland and Europe. On the one hand, the Swiss rail transport is operated only by electric trains powered almost exclusively by hydroelectric energy, using diesel trains only for shunting activity. On the other hand, European rail transport is a mix of diesel and electric traction (as in the case of Belgium). Whilst in both cases the energy consumption was almost the same, the environmental life cycle performance of Swiss rail transport was better as a result of the use of trains powered by hydroelectric energy. In addition, they showed the importance of infrastructure in the LCA of transport systems.

Facanha and Horvath $(2006,2007)$ performed an environmental assessment of the life cycle of rail, road and air freight transport in the USA. They considered that rail freight transport in the USA is predominantly performed by diesel traction and the rail infrastructure is only dedicated to goods transport. Their results showed that rail freight transport presents less emissions of $\mathrm{CO}_{2}, \mathrm{NO}_{\mathrm{X}}, \mathrm{CO}$ and $\mathrm{PM}_{10}$ than road transport. Moreover, they concluded that transport operation is the more important transport life cycle stage for $\mathrm{CO}_{2}$ emissions in every transport mode and the infrastructure is an important source of $\mathrm{PM}_{10}$. They highlighted the importance of considering the life cycle emissions in new transport policies. For passenger transport, Chester and Horvath (2009) performed an environmental assessment of the life cycle of automobiles, buses, trains and airplanes in the USA. They also emphasize the importance of considering the entire life cycle when analysing the energy consumption, GHG emissions and air pollution in transport.

Spielmann et al. (2007) carried out the most complete Life Cycle Inventory (LCI) on transport for both passengers and goods. This study was used to develop the transport processes in the Ecoinvent database, and therefore it has been adopted as a model for our research.

Stripple and Uppenberg (2010) investigated the LCA of a newly constructed railway line in Sweden, used by both passenger and freight transport. Considering a life of 60 years for the infrastructure and that trains are powered by hydroelectric energy, the train traffic (which includes the stages of transport operation and rail equipment) accounts for $56.7 \%$ and the rail infrastructure for $43.3 \%$ of the total primary energy consumption. For global warming potential, the train traffic accounts for $6.7 \%$ and the rail infrastructure for $93.3 \%$. The small GHG emissions of train traffic are a result of the use of hydroelectric power as energy traction, and the main GHG emissions of rail infrastructure are due to the production of materials, being the contribution of the infrastructure construction works smaller.

Fries and Hellweg (2014) performed a LCA of rail and road freight transport in Switzerland and some European transport routes. Their results showed that rail freight transport is the land transport option that has the highest environmental performance compared to intermodal road-rail and all-road transport.

In view of the foregoing, the following questions arise: what type of rail traction (diesel or electric) in Belgium has a better environmental life cycle performance? What role does the railway infrastructure play in the environmental impact of rail transport in Belgium? Does it vary in importance depending on the type of traction used? How does the electricity supply mix affect the environmental impact of electric trains in different countries? Could an electric train, depending on the type of electricity used, have a greater or lesser impact than a diesel train?

The purpose of this paper is to determine the environmental impact of rail freight transport in Belgium using the LCA methodology, including a comprehensive study of the Belgian rail infrastructure. Furthermore, we have carried out a comparison of the environmental impact of electric trains in several countries of Europe, and thus analysing how the electricity supply mix affects the environmental impact of electric trains in different countries. This paper includes data for Belgium from the period 2006 to 2012. This is because the most recent data available on energy consumption for rail freight transport in Belgium are from 2012. Note that 
the liberalization of the Belgian rail freight market has led to a greater difficulty in obtaining data on energy consumption because this information has become a competitive edge for railway freight transport companies (Merchan et al. 2019).

\section{Methods}

The LCA methodology is internationally standardized by ISO Standards 14040 and 14044 (ISO 2006a, b), and it is a structured and comprehensive method that allows to analyse and compare the environmental impacts of products and systems like rail freight transport. Thereby, it enables to assess and quantify all significant consumption and emissions, as well as the related environmental impacts through all the stages of the rail freight transport system: transport operation, rail equipment and infrastructure. Thus, through the application of the LCA methodology, the contribution of the pollutants emitted by rail freight transport can be analysed using environmental impact categories such as climate change, particulate matter emissions or resource depletion for example (European Commission 2010).

A LCA study comprises four stages. The first stage is the goal and scope definition, which in this paper is to determine the environmental impacts of rail freight transport in Belgium. The functional unit chosen is " $1 \mathrm{tkm}$ of freight transported by train".

The second stage of a LCA is the inventory analysis (i.e. LCI). At present, no state of the art for rail freight transport in Belgium has been published (e.g. rolling stock or railway network characteristics). Hence, at first, we used the Ecoinvent v3 database to identify which processes are the most relevant to determine the environmental impact of rail freight transport (Spielmann and Scholz 2005). Then, based on this preliminary assessment, we have collected countryspecific data on the rail freight transport system through the use of questionnaires from both the Belgian railway infrastructure manager (Infrabel) and the main rail freight operator. (LINEAS transported the $86.6 \%$ of tkm of rail freight in Belgium in 2012 (Van de Voorde and Vanelslander 2014).) Eventually, we have complemented the information using literature sources and the Ecoinvent database.

The third stage is the Life Cycle Impact Assessment (LCIA). We modelled the rail freight transport system using the LCA software SimaPro 8.0.5 and performed the impact assessment with the LCIA method ILCD 2011 Midpoint+ (version V1.06/EU27 2010). This LCIA method is recommended by the European Commission, and it encompasses 16 environmental impact indicators (European Commission 2010). However, in order to facilitate the interpretation of LCIA results, in this study only the indicators with a level of quality I (climate change, ozone depletion and particulate matter) and II (ionizing radiation-human health, photochemical ozone formation, acidification, terrestrial and freshwater eutrophication and mineral, fossil and renewable resource depletion) have been used. Finally, the fourth stage is the assessment of the results obtained in the previous stages (i.e. LCI and LCIA).

Figure 1 defines the system boundaries considered in our study for the rail freight transport system, which consists of three sub-systems: rail transport operation, rail equipment (locomotives and wagons) and rail infrastructure. The rail transport operation comprises the processes related to the train activity. For diesel trains, it encompasses the exhaust emissions from diesel locomotives and the indirect emissions from diesel refining. For electric trains, it includes the sulphur hexafluoride $\left(\mathrm{SF}_{6}\right)$ leakage from traction substations and the indirect emissions from the production of electricity. Note that $\mathrm{SF}_{6}$ is used as an insulating gas in the transformers of traction substations, where the electricity from the power grid is converted to a form suitable for the railway network and $\mathrm{SF}_{6}$ leakage may occur. Since the electricity supply mix contributes significantly to the environmental performance of electric trains, we have modelled the electricity supply

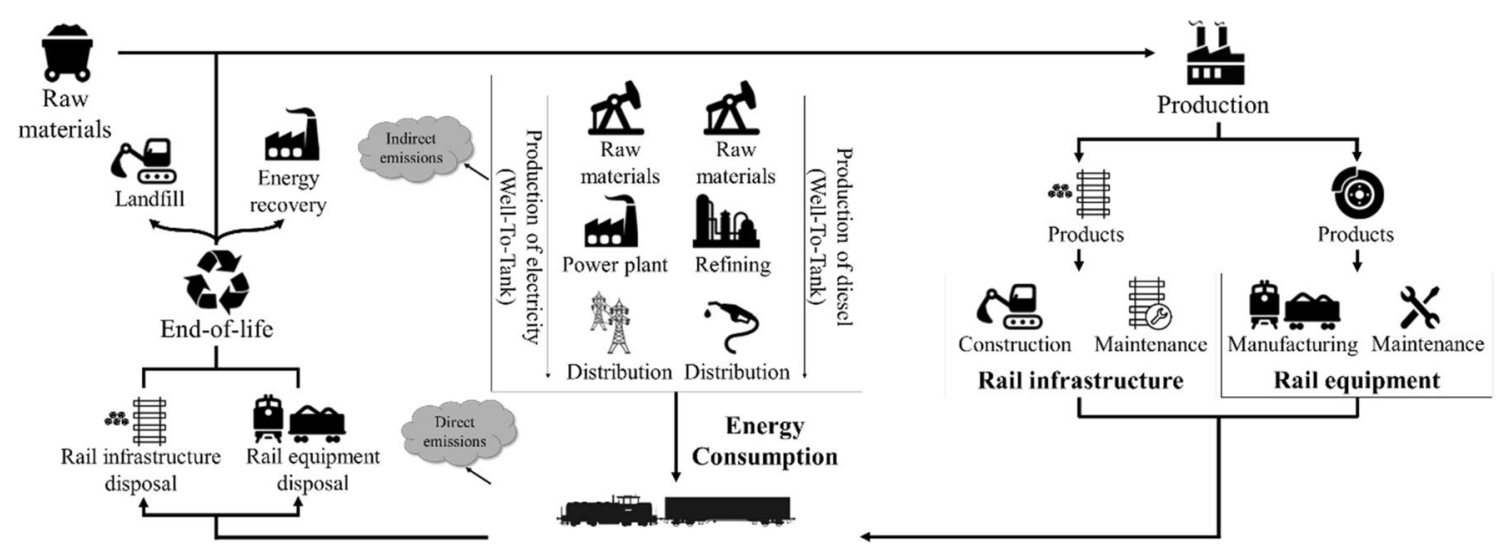

Fig. 1 System boundaries considered for the Belgian rail freight transport 
mix used for the electric trains in Belgium for each year. Furthermore, the direct emissions to soil from the wear between the brake-wheel and wheel-rail interfaces are also included in the sub-system rail transport operation. The sub-system rail equipment comprises the manufacturing, maintenance and disposal of locomotive and wagons. Likewise, the construction, maintenance and disposal of the railway network are considered in the sub-system rail infrastructure (Spielmann et al. 2007).

\section{Rail transport operation}

The sub-system rail transport operation encompasses both indirect and direct processes connected with the overall life cycle of the energy carrier. The indirect processes (also referred to as Well-To-Tank stage) include the primary energy consumption and indirect emissions released from the raw material extraction, continuing with the diesel refining or electricity generation and finishing with the energy supply to the train. Thus, the analysis of the electricity supply mix used by electric trains is included in this stage. The direct processes (also referred to as Tank-To-Wheels stage) comprise the energy consumption of electric and diesel trains during the transport activity and the direct emissions such as the exhaust emissions from diesel locomotives and the $\mathrm{SF}_{6}$ leakage from the transformers of traction substations (where the gas is used as electrical insulator) related to electricity consumption. Furthermore, the direct emissions to soil from the wear between the brake-wheel and wheel-rail interfaces are also included in this sub-system.

We have calculated the energy consumption during the rail transport activity for three different modes of rail freight transport in Belgium for the period from 2006 to 2012: electric trains, diesel trains and the Belgian traction mix (Table 1). Firstly, the values for electric and diesel trains have been calculated independently on the basis of both the total annual energy consumption of electricity or diesel and the total annual rail freight moved by each energy traction. Annual data on energy consumption of trains include empty returns, shunting activity, maintenance of trains, as well as electrical losses in catenary (Merchan et al. 2017).
Secondly, the energy consumption of the Belgian traction mix has been determined using the energy consumption of electric and diesel trains and the rail freight traction share. The total energy consumption of rail freight transport considering the Belgian traction mix is the sum of electricity and diesel consumption (e.g. the total energy consumption of the Belgian traction mix is $457 \mathrm{~kJ} / \mathrm{tkm}$ in the year 2012). For the rail freight traction share, we have used data from Flanders (Belgian region) as there are no data at country level and these values can be considered representative for Belgium. (The values for 2006 and 2010 have been obtained by linear interpolation.) Note that in Belgium the use of electric traction predominates over diesel traction and this, together with the decrease in diesel traction over the years, results in that only a limited part of the Belgian rail freight transport releases exhaust emissions.

According to EcoTransIT (2008), electric and diesel trains present an energy consumption of $456 \mathrm{~kJ} / \mathrm{tkm}$ and $530 \mathrm{~kJ} / \mathrm{tkm}$, respectively. These values represent European averages of the year 2005 and comprise both the final energy consumption during transport operation and the energy consumption of the generation of diesel and electricity (EcoTransIT 2008). Electric trains present in our study lower energy consumptions after the year 2010, and the values calculated for diesel trains (including shunting activity) show higher energy consumptions than the values of EcoTransIT (2008). Therefore, electric trains are more energy efficient than diesel trains.

In the case of the energy consumption in the Belgian traction mix, Ecoinvent $\mathrm{v} 3$ database presents a consumption of $260 \mathrm{~kJ}$ of electricity and $157 \mathrm{~kJ}$ of diesel to move $1 \mathrm{tkm}$ of rail freight in Belgium in the year 2014. By comparing with our results, $368 \mathrm{~kJ}$ of electricity and $89 \mathrm{~kJ}$ of diesel (including shunting activity) were needed to move $1 \mathrm{tkm}$ in Belgium in the year 2012. As in our study, the values of energy consumption extracted from the Ecoinvent v3 database represent the final energy consumption during transport operation. The results of final electricity consumption from our study are always higher than the value used by Ecoinvent v3. However, since the year 2009 , the final diesel consumption from our study shows values lower than the value from

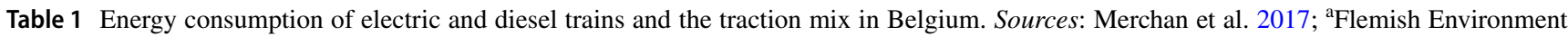
Agency (VMM 2008, 2009, 2010, 2012, 2013)

\begin{tabular}{|c|c|c|c|c|c|c|c|c|c|}
\hline \multicolumn{3}{|l|}{ Year } & 2006 & 2007 & 2008 & 2009 & 2010 & 2011 & 2012 \\
\hline \multicolumn{3}{|c|}{ Electricity consumption of electric trains $(\mathrm{kJ} / \mathrm{tkm})$} & 541 & 527 & 549 & 547 & 438 & 454 & 427 \\
\hline \multicolumn{3}{|c|}{ Diesel consumption of diesel trains $(\mathrm{kJ} / \mathrm{tkm})$} & 725 & 685 & 746 & 804 & 760 & 608 & 650 \\
\hline \multirow[t]{4}{*}{ Belgian traction mix } & Electric traction & Traction share $(\%)^{\mathrm{a}}$ & 76.3 & 76 & 78.2 & 83.1 & 83.5 & 83.8 & 86.3 \\
\hline & & Electricity consumption $(\mathrm{kJ} / \mathrm{tkm})$ & 413 & 400 & 429 & 454 & 365 & 380 & 368 \\
\hline & Diesel traction & Traction share $(\%)^{\mathrm{a}}$ & 23.7 & 24 & 21.8 & 16.9 & 16.6 & 16.2 & 13.7 \\
\hline & & Diesel consumption $(\mathrm{kJ} / \mathrm{tkm})$ & 172 & 164 & 163 & 136 & 126 & 98 & 89 \\
\hline
\end{tabular}


Ecoinvent v3. The discrepancies between the values of our study and those of Ecoinvent v3 should be highlighted, since they point out a need for updating the Ecoinvent v3 database.

The energy consumption of rail transport is influenced by external factors to the train as the orography and factors related to the train characteristics such as speed, acceleration, length and total weight (Spielmann et al. 2007). In Belgium, the energy consumption depends on whether the rail transport takes place in the flat terrain near the coast or is performed in the hilliest area of the south, where actual consumptions are higher. Moreover, the energy consumption of a freight train decreases per tkm with a low average speed and making few stops along the route (Infrabel 2014).

Furthermore, the longer the train and the heavier the cargo, rail freight transport becomes more energy efficient (Messagie et al. 2014). In the Belgian network, the length of freight trains is limited to $750 \mathrm{~m}$ and the maximum permitted load is $3600 \mathrm{t}$ with an axle load up to $22.5 \mathrm{t}$ on flat terrain, decreasing in mountainous terrain (Service Public Wallonie 2012). The maximum authorized load is fixed considering the characteristics of the line section (e.g. gradient, curves or number of tracks) and the train (e.g. adhesion and power) (Infrabel 2014). The average load of freight trains in Belgium was $569 \mathrm{t}, 575 \mathrm{t}$ and $584 \mathrm{t}$ in the years 2006, 2007 and 2008, respectively (SNCB 2009). Note that the use of electric locomotives rather than diesel locomotives enables one to transport heavier loads.

The improvement in the energy efficiency of rail freight transport can be achieved by implementing a broad range of actions. Among the most important energy-saving measures, let us mention: improving the energy performance of engines or railway electrification systems to avoid energy losses, developing energy-efficient driving strategies as control of speed, enhancing the regenerative braking technology, increasing the aerodynamic efficiency of trains and optimizing the railway network (Douglas et al. 2015).

The direct emissions produced during the train activity have been calculated using the emission factors drawn from various sources by Spielmann et al. (2007). For diesel trains, the exhaust emissions to air produced from the combustion of diesel have been determined based on fuel consumption. In the case of the exhaust $\mathrm{SO}_{2}$ emissions, they are dependent on the sulphur content in diesel. In Belgium, where diesel trains operate with conventional road transport diesel, the amount of sulphur by mass permissible for diesel is $10 \mathrm{ppm}$ from 2009. However, diesel in Belgium has a sulphur concentration of $8 \mathrm{ppm}$ since 2008. Moreover, the sulphur content in diesel in Belgium was $24 \mathrm{ppm}$ in 2006 and 9 ppm in 2007 (Twisse and Scott 2012). Note that the fuel quality legislation is an effective measure to reduce the exhaust $\mathrm{SO}_{2}$ emissions. For electric trains, the $\mathrm{SF}_{6}$ leakage from the transformers of traction substations has been calculated based on electricity consumption. Furthermore, the direct emissions to soil from the wear between the brake-wheel and wheel-rail interfaces have been calculated for both types of traction as well. To determine particle emissions, it is necessary to add the particles produced by the abrasion to those produced by the combustion of diesel.

For electric trains, we have modelled the electricity supply mix of Belgium for each year as the energy split varies throughout the years. We consider the environmental impacts related to electricity from the raw materials extraction (e.g. uranium or oil), continuing with electricity production at the power plant and ending with the electricity distribution (including transmission and distribution losses) to the traction unit. The electricity supply mix used by electric trains has been modelled considering the Belgian electricity production in addition to exports and imports of electricity from The Netherlands, France and Luxembourg. The electricity imported from these countries has been also calculated taking into account their supply mix. Moreover, the production of solar energy by Infrabel in the years 2011 and 2012 has been included as well. The process "Electricity, high voltage $\{B E\} \mid$ market for I Alloc Rec, U" from Ecoinvent has been adopted as a model to convert the data from Eurostat on energy sources (Eurostat statistics 2017) to the technologies used in the electricity generation.

\section{Rail equipment}

For the manufacturing, maintenance and disposal of locomotives and wagons, instead of collecting new data specific to Belgium such as material composition or energy consumption in maintenance work for example, we have used the Ecoinvent v3 database. The locomotive and wagons demand has been determined on the basis of the total annual transport performance of freight transport (i.e. tkm) and the number of goods transport wagons and locomotives used in Belgium by each energy traction from the period 2006 to 2012. Since the number of wagons used in diesel and electric traction separately is not available, the same wagon demand in both energy tractions has been used. In the year 2015, LINEAS owned 201 locomotives for freight transport, being 86 electric locomotives and 115 diesel locomotives. For locomotives and wagons, a lifespan of 40 years has been considered (Spielmann et al. 2007).

\section{Rail infrastructure}

A comprehensive study of the Belgian railway network has been performed, collecting country-specific data on the construction, maintenance and disposal of infrastructure. All the processes included in this sub-system have been calculated using a double-track railway line as reference. However, according to the available data, the Belgian railway network is categorized into two groups of railway lines: one track and 
two or more tracks. In order to obtain the length of the Belgian railway network on double-track railway line, we have first converted the length of the single-track railway lines to double-track railway lines and then we have added the length of the two or more tracks railway lines (Table 2). The values of one and two tracks railway lines for years 2011 and 2012 have been calculated using linear interpolation.

\section{Allocation factors of the railway infrastructure between freight and passenger transport}

An allocation of the processes connected to the rail infrastructure has been conducted as the railway network is used by passenger and goods transport. The allocation principle for the construction and disposal of rail infrastructure is the train weigh and for the maintenance and operation is the temporal occupation of the infrastructure (Spielmann et al. 2007).

The allocation factors of infrastructure construction and disposal for the Belgian railway infrastructure have been calculated on the basis of the transport performance (tkm) and operating performance (Gtkm, i.e. transport of 1 tonne of hauled vehicles and content, thus including the weight of the wagons, over a distance of $1 \mathrm{~km}$ ) for freight and passenger transport in Belgium. Note that data on traction performance (GGtkm, i.e. transport of 1 tonne of railway vehicle, thus including the weight of the load, wagons and locomotive, over a distance of $1 \mathrm{~km}$ ) are not available. Firstly, the length of the Belgian railway network in double-track railway lines has been divided by the total operating performance $(\mathrm{Gtkm})$ of freight and passenger transport. Secondly, the ratio Gtkm/ tkm for freight transport and Gtkm/pkm for passenger transport has been obtained. Thirdly, the values determined in the first and second step have been multiplied to obtain the rail infrastructure demand per tkm referred to $1 \mathrm{~m}$ and year $(\mathrm{m} \times \mathrm{a})$ for freight transport $((\mathrm{m} \times \mathrm{a}) / \mathrm{tkm})$ and passenger transport $((\mathrm{m} \times \mathrm{a}) / \mathrm{pkm})$.

The allocation factors of infrastructure maintenance and operation have been determined on the basis of the transport performance $(\mathrm{tkm})$ and kilometric performance (train-km, i.e. the movement of a train over a distance of $1 \mathrm{~km}$ ) for freight and passengers transport in Belgium. The same methodology as for construction and disposal of infrastructure has been used, but instead of the total operating performance has been used the total kilometric performance (train- $\mathrm{km}$ ), and the ratios $\mathrm{Gtkm} / \mathrm{tkm}$ and $\mathrm{Gtkm} / \mathrm{pkm}$ have been replaced by the ratios train $-\mathrm{km} / \mathrm{tkm}$ for freight transport and train$\mathrm{tkm} / \mathrm{pkm}$ for passenger transport.

Table 3 shows data on transport, operating and kilometric performance for freight and passenger transport in Belgium. The values of operating performance for the years 2011 and 2012 have been obtained considering that the variation of Gtkm is approximately the same as the variation of tkm or passenger-kilometre (pkm). Moreover, the values of kilometric performance for the years 2010 and 2012 have been calculated using linear interpolation.
Table 2 Length of railway lines in Belgium (km). Sources: Eurostat statistics (2017) and ${ }^{\mathrm{a} S}$ Statistics Belgium (2017)

\begin{tabular}{lrrrrrrl}
\hline & 2006 & 2007 & 2008 & 2009 & $2010^{\text {a }}$ & 2011 & 2012 \\
\hline Total standard gauge & 3560 & 3568 & 3513 & 3578 & 3582 & - & - \\
One track railway lines & 825 & 828 & 744 & 796 & 722 & 718 & 713 \\
Two tracks or more railway lines & 2735 & 2740 & 2769 & 2782 & 2860 & 2876 & 2891 \\
Total double-track railway line calculated & 3148 & 3154 & 3141 & 3180 & 3221 & 3235 & 3248 \\
\hline
\end{tabular}

Table 3 Goods and passenger transport in Belgium. Sources: Eurostat statistics (2017), Statistics Belgium (2017), SNCB (2009, 2013, 2015) and UIC (2010)

\begin{tabular}{llrrrrrrr}
\hline & & 2006 & 2007 & 2008 & 2009 & 2010 & 2011 & 2012 \\
\hline Transport performance (million tkm and pkm) & Freight & 8442 & 8148 & 7882 & 5439 & 5729 & 5913 & 5220 \\
& Passenger & 9607 & 9932 & 10,403 & 10,426 & 10,609 & 10,848 & 10,857 \\
Operating performance (million Gtkm) & Total & 46,381 & 45,940 & 45,663 & 40,595 & 42,835 & 43,921 & 42,417 \\
& Freight & 20,014 & 18,987 & 18,794 & 12,995 & 12,645 & 13,051 & 11,522 \\
& Passenger & 25,664 & 26,308 & 26,287 & 27,001 & 30,190 & 30,870 & 30,896 \\
Kilometric performance (million train-km) & Other trains ${ }^{\mathrm{a}}$ & 703 & 645 & 582 & 599 & - & - & - \\
& Total & 96 & 97 & 96 & 93 & 93 & 95 & 94 \\
& Freight & 15 & 15 & 15 & 12 & 13 & 12 & 12 \\
& Passenger & 78 & 80 & 80 & 81 & 81 & 82 & 83 \\
& Other trains ${ }^{\mathrm{a}}$ & 3 & 3 & 3 & 3 & - & - & - \\
\hline
\end{tabular}

${ }^{\text {a}}$ Trains moving only for the requirements of the railway enterprise 
Table 4 presents the different demand factors for the Belgian railway infrastructure. The demand factors of infrastructure construction and maintenance are the same for rail freight transport (i.e. Belgian traction mix), electric trains and diesel trains. Since the main use of the Belgian railway infrastructure is passenger transport, rail freight transport presents a lower railway infrastructure demand than passenger transport in both the construction and disposal of railway infrastructure and the operation and maintenance of railway infrastructure. Note that the difference on railway infrastructure demand between passenger and freight transport is much greater in the operation and maintenance than in the construction and disposal of railway infrastructure. This is because passenger transport presents a more intensive use of the railway infrastructure (between five and seven times more than rail freight transport, see the values on kilometric performance in Table 3), but the transported mass of passenger and goods are more similar. (See the values on kilometric and operating performance in Table 3.)

\section{Railway construction}

The most significant components of the rail infrastructure have been included in our study: tunnels, bridges, track bedding, rails, sleepers, fastening system, switch and crossing system, and the overhead contact system.

\section{Tunnels and bridges}

The material demand for the construction of tunnels and bridges has been calculated using data from Schmied and Mottschall (2013), which analyse the German railway infrastructure (Table 5). Two types of tunnels have been distinguished with different material demand requirements. The mined tunnels are constructed by drilling and blasting or using tunnel boring machines, and the trenched tunnels are built through an open excavation, which is refilled once is completed. The difference in energy consumption between mined and trenched tunnels is the use of tunnel boring machines in the former (Schmied and Mottschall 2013). Moreover, Table 5 shows the material demand for tunnel and bridge construction from Von Rozycki et al. (2003), which focus on the German high-speed rail infrastructure and have been used by Spielmann et al. (2007) to develop the rail freight transport processes in the Ecoinvent $v 3$ database.

Tuchschmid et al. (2011) considered for the Belgian railway network in the year 2008 a share of $25 \%$ and $75 \%$ for trenched tunnels and mined tunnels, respectively. Since no

Table 4 Railway infrastructure demand for rail transport in Belgium

\begin{tabular}{|c|c|c|c|c|c|c|c|c|c|}
\hline & & 2005 & 2006 & 2007 & 2008 & 2009 & 2010 & 2011 & 2012 \\
\hline \multirow[t]{2}{*}{$\begin{array}{l}\text { Construction and } \\
\text { disposal }\end{array}$} & $\begin{array}{l}\text { Freight }((\mathrm{m} \times \mathrm{a}) / \\
\quad \mathrm{tkm})\end{array}$ & $1.68 \times 10^{-4}$ & $1.61 \times 10^{-4}$ & $1.60 \times 10^{-4}$ & $1.64 \times 10^{-4}$ & $1.87 \times 10^{-4}$ & $1.66 \times 10^{-4}$ & $1.63 \times 10^{-4}$ & $1.69 \times 10^{-4}$ \\
\hline & $\begin{array}{l}\text { Passengers } \\
\qquad((\mathrm{m} \times \mathrm{a}) / \mathrm{pkm})\end{array}$ & $1.87 \times 10^{-4}$ & $1.81 \times 10^{-4}$ & $1.82 \times 10^{-4}$ & $1.74 \times 10^{-4}$ & $2.03 \times 10^{-4}$ & $2.14 \times 10^{-4}$ & $2.10 \times 10^{-4}$ & $2.18 \times 10^{-4}$ \\
\hline \multirow[t]{2}{*}{$\begin{array}{l}\text { Operation and } \\
\text { maintenance }\end{array}$} & $\begin{array}{l}\text { Freight }((\mathrm{m} \times \mathrm{a}) / \\
\quad \text { tkm })\end{array}$ & $6.24 \times 10^{-5}$ & $5.73 \times 10^{-5}$ & $6.01 \times 10^{-5}$ & $6.18 \times 10^{-5}$ & $7.31 \times 10^{-5}$ & $7.77 \times 10^{-5}$ & $7.12 \times 10^{-5}$ & $7.74 \times 10^{-5}$ \\
\hline & $\begin{array}{l}\text { Passengers } \\
\qquad((\mathrm{m} \times \mathrm{a}) / \mathrm{pkm})\end{array}$ & $2.74 \times 10^{-4}$ & $2.66 \times 10^{-4}$ & $2.60 \times 10^{-4}$ & $2.51 \times 10^{-4}$ & $2.64 \times 10^{-4}$ & $2.65 \times 10^{-4}$ & $2.59 \times 10^{-4}$ & $2.62 \times 10^{-4}$ \\
\hline
\end{tabular}

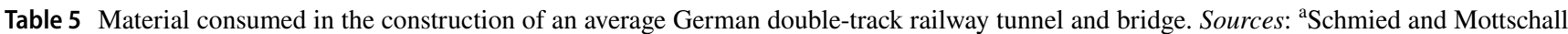

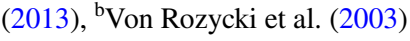

\begin{tabular}{|c|c|c|c|c|c|c|c|c|c|}
\hline & \multicolumn{5}{|c|}{ German railway infrastructure $^{\mathrm{a}}$} & \multicolumn{4}{|c|}{ German high-speed rail infrastructure ${ }^{b}$} \\
\hline & \multicolumn{2}{|l|}{ Tunnel } & \multicolumn{3}{|l|}{ Bridge } & \multicolumn{2}{|l|}{ Tunnel } & \multicolumn{2}{|l|}{ Bridge } \\
\hline & Mined & Trenched & Viaducts & Concrete & Iron & Mined & Trenched & Rail glen & $\begin{array}{l}\text { Railroad } \\
\text { and road- } \\
\text { way }\end{array}$ \\
\hline Share of tunnel type & $75 \%$ & $25 \%$ & - & - & - & $61 \%$ & $29 \%$ & - & - \\
\hline Lifespan (years) & 60 & 60 & 60 & 60 & 60 & 100 & 100 & 100 & 50 \\
\hline Concrete $\left(\mathrm{m}^{3} / \mathrm{m}\right)$ & 37.2 & 49 & 31.6 & 14 & - & $44 \mathrm{t} / \mathrm{m}$ & $71 \mathrm{t} / \mathrm{m}$ & $55 \mathrm{t} / \mathrm{m}$ & $89 \mathrm{t} / \mathrm{m}$ \\
\hline Steel $(\mathrm{t} / \mathrm{m})$ & 1.6 & 6.1 & 3.51 & 1.5 & 7.2 & 2.1 & 2.8 & 3 & 4.9 \\
\hline Excavation soil $\left(\mathrm{m}^{3} / \mathrm{m}\right)$ & 127.9 & 300 & 26.17 & 5.234 & 5.234 & $270 \mathrm{t} / \mathrm{m}$ & $700 \mathrm{t} / \mathrm{m}$ & - & - \\
\hline Electricity (MWh/m) & 2.2 & 0.5 & - & - & - & - & - & - & - \\
\hline Diesel (L/m) & 140 & 100 & 8.4 & 6.1 & 6.1 & - & - & - & - \\
\hline
\end{tabular}


data are available for Belgium, they used the same proportion as the German railway network, which is based on an assumption of Schmied and Mottschall (2013). Tuchschmid et al. (2011) use for the Belgian railway network a share of $26 \%$ for viaducts, $57 \%$ for concrete bridges and $17 \%$ for iron bridges. Table 6 presents the material demand for tunnel and bridge construction using the parameters of construction from Schmied and Mottschall (2013) and the reference values from Spielmann et al. (2007).

The material demand from tunnel and bridge construction in the Belgian railway network has been calculated considering the share of tunnels and bridges. The Belgian railway network has 132 tunnels and 4800 bridges. The total length of tunnels is $95 \mathrm{~km}$, which represents approximately 27 metres of tunnel per kilometre or $2.6 \%$ of the Belgian railway network. Tuchschmid et al. (2011) considered for the Belgian railway network a share of $1.3 \%$ of tunnels in the year 2008. Since the total length of bridges is unavailable, it has been used a share of bridges for the Belgian railway network of 2.2\% from Tuchschmid et al. (2011).

\section{Track bedding, rails, sleepers and fastening system}

The railway track foundation for a single track used in the Belgian railway network is composed on average for a single track of an upper base of $3200 \mathrm{~kg} / \mathrm{m}$, a subbase of $3550 \mathrm{~kg} / \mathrm{m}$ and a subgrade of $7100 \mathrm{~kg} / \mathrm{m}$. Given a lifespan of 40 years (Infrabel 2016), a material demand of $692.5 \mathrm{~kg} /(\mathrm{m} \times \mathrm{a})$ of gravel for a double-track railway line is obtained. We have considered only ballasted tracks in our study.

There are two major types of rail profiles in the Belgian railway network, the rail $50 \mathrm{E} 2(50 \mathrm{~kg} / \mathrm{m})$ and the rail $60 \mathrm{E} 1$ $(60 \mathrm{~kg} / \mathrm{m})$, with an average ratio of $53 \%$ and $47 \%$, respectively. Furthermore, the use of continuously welded rails of $300 \mathrm{~m}$ long and three splice bars per $\mathrm{km}$ (piece of steel that joins two rails) has been included. The weight of the splice bars used for the rails $50 \mathrm{E} 2$ and $60 \mathrm{E} 1$ is $13.9 \mathrm{~kg} / \mathrm{unit}$ and $19 \mathrm{~kg} / \mathrm{unit}$, respectively. Considering a lifespan of 30 years for the rails and splice bars (Von Rozycki et al. 2003), the steel demand for a double-track railway line is $7.29 \mathrm{~kg} /$ $(\mathrm{m} \times \mathrm{a})$ from rails and $0.0072 \mathrm{~kg} /(\mathrm{m} \times \mathrm{a})$ from splice bars, resulting in a total steel demand of $7.3 \mathrm{~kg} /(\mathrm{m} \times \mathrm{a})$.

In the Belgian railway network, sleepers are spaced at $0.6 \mathrm{~m}$ in main lines and $0.75 \mathrm{~m}$ in side lines, resulting in an average of 1.67 and 1.3 sleepers per metre, respectively (Infrabel 2007). The spacing of $0.6 \mathrm{~m}$ is similar to those of the main Swiss railway lines (Künniger and Richter 1998) and the Swedish railway lines (Stripple and Uppenberg 2010). Bolin and Smith (2013) describe a distance between wooden and plastic composite sleepers of $0.495 \mathrm{~m}$, and for concrete sleepers of $0.61 \mathrm{~m}$ for the US railway network.

According to a manufacturer of concrete sleepers for the Belgian railway network, concrete sleepers type M41 have a total weight of $294 \mathrm{~kg}$, including $286.2 \mathrm{~kg}$ of concrete and $7.8 \mathrm{~kg}$ of steel reinforcement (PREFER 2006). As shown in Table 7, Künniger and Richter (1998) describe the concrete sleepers used in the main Swiss railway lines made of $258 \mathrm{~kg}$ of concrete and $14 \mathrm{~kg}$ of reinforcement steel, Ueda et al. (1999) describe the use of concrete sleepers in the Japanese railway network made of $155 \mathrm{~kg}$ of concrete and $4.8 \mathrm{~kg}$ of reinforcing steel, Stripple and Uppenberg (2010) describe the use in a new constructed single-track railway in Sweden of concrete sleepers made of $250 \mathrm{~kg}$ of concrete and $6.1 \mathrm{~kg}$ of steel reinforcement, and Bolin and Smith (2013) describe the use of concrete sleepers of $318 \mathrm{~kg}$ in the USA, including the reinforcing steel. As mentioned above, Ecoinvent v3 database takes the values from Von Rozycki et al. (2003), which performed a study of a high-speed railway track in Germany, considering a material use due to concrete sleepers of $990 \mathrm{t}$ of concrete and $39 \mathrm{t}$ of steel per rail track kilometre in a two-way line. If we consider a distance between sleepers of $0.6 \mathrm{~m}$ (1.67 sleeper/m), it results in $297 \mathrm{~kg}$ of concrete and $11.7 \mathrm{~kg}$ of steel per sleeper. By comparing the concrete sleeper considered in our study, a greater material consumption is considered than Stripple and Uppenberg (2010), Ueda et al. (1999) and Künniger and Richter (1998) with the exception of the steel reinforcement used in the main Swiss railway lines. Bolin and Smith (2013) and the calculations made by Von Rozycki et al. (2003) show the highest material consumption than our study.
Table 6 Material demand for tunnel and bridge construction.

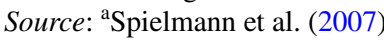

\begin{tabular}{llllll}
\hline & \multicolumn{2}{l}{ Belgium } & & \multicolumn{2}{l}{ Switzerland $^{\mathrm{a}}$} \\
& Tunnel & Bridge & & Tunnel & Bridge \\
\hline Concrete, high exacting $\left(\mathrm{m}^{3} /(\mathrm{m} \times \mathrm{a})\right)$ & 0.669 & 0.27 & & 0.261 & 0.306 \\
Reinforcing steel $(\mathrm{kg} /(\mathrm{m} \times \mathrm{a}))$ & 45.417 & 49.86 & & 24.5 & 36.8 \\
Excavation soil $(\mathrm{kg} /(\mathrm{m} \times \mathrm{a}))$ & $2.849 \mathrm{~m}^{3} /(\mathrm{m} \times \mathrm{a})$ & 0.178 & & 4850 & - \\
Gravel, crushed $(\mathrm{kg} /(\mathrm{m} \times \mathrm{a}))$ & 583 & - & & 583 & - \\
Diesel $(\mathrm{MJ} /(\mathrm{m} \times \mathrm{a}))^{\mathrm{b}}$ & 77.9 & 4 & & 135 & - \\
Electricity $(\mathrm{kWh} /(\mathrm{m} \times \mathrm{a}))$ & 29.6 & - & & 56.9 & - \\
\hline
\end{tabular}

${ }^{\mathrm{b}}$ Considering that the density of diesel is $0.84 \mathrm{~kg} / \mathrm{L}$ and diesel net calories are $42.8 \mathrm{MJ} / \mathrm{kg}$ 
Table 7 Comparison of material profile of sleepers from different sources. Sources: ${ }^{a}$ Künniger and Richter (1998), ${ }^{b}$ Ueda et al. (1999), ${ }^{\mathrm{c}}$ Stripple and Uppenberg (2010), ${ }^{\mathrm{d} B o l i n}$ and Smith (2013) and ${ }^{\mathrm{e}}$ Von Rozycki et al. (2003)

\begin{tabular}{|c|c|c|c|c|c|c|c|}
\hline & Material & $\begin{array}{l}\text { Belgium (kg/ } \\
\text { sleeper) }\end{array}$ & $\begin{array}{l}\text { Switzerland }^{\mathrm{a}} \\
\text { (kg/sleeper) }\end{array}$ & $\begin{array}{l}\text { Japan }^{\mathrm{b}}(\mathrm{kg} / \\
\text { sleeper) }\end{array}$ & $\begin{array}{l}\text { Sweden }^{\mathrm{c}}(\mathrm{kg} / \\
\text { sleeper) }\end{array}$ & $\mathrm{USA}^{\mathrm{d}}$ (kg/sleeper) & $\begin{array}{l}\text { Germany } \\
\text { (double- } \\
\text { track) }\end{array}$ \\
\hline \multirow[t]{3}{*}{ Concrete sleeper } & Concrete & 286.2 & 258 & 155 & 250 & 318 & $990 \mathrm{t} / \mathrm{km}$ \\
\hline & Steel & 7.8 & 14 & 4.8 & 6.1 & & $39 \mathrm{t} / \mathrm{km}$ \\
\hline & Lifespan & 40 & $35-45$ & 50 & - & 40 & 30 \\
\hline \multirow[t]{3}{*}{ Wooden sleeper } & Wood & 80 & 62 & $56-58$ & - & $0.093-0.11 \mathrm{~m}^{3} / \mathrm{sleeper}$ & - \\
\hline & Creosote & 5.07 & 15.2 & 14 & - & $88 \mathrm{~kg} / \mathrm{m}^{3}$ & - \\
\hline & Lifespan & 25 & $24-30$ & 15 & & 35 & - \\
\hline \multirow[t]{2}{*}{ Steel sleeper } & Steel & 70 & 91 & 55 & - & - & - \\
\hline & Lifespan & 35 & $30-45$ & 50 & - & - & - \\
\hline
\end{tabular}

The wooden sleepers used in the Belgian railway network are made of $80 \mathrm{~kg}$ of oak (Quercus petraea or Quercus robur) with a lifespan of 25 years (Infrabel 2016). The use of beech is no longer permitted. The wood for manufacturing sleepers is produced in a framework of sustainable forest management certified by an independent body, such as the certifications FSC and PEFC (Infrabel 2011). The wooden sleepers are dried and creosoted to preserve the wood in the Wondelgem workshop of Infrabel. The creosote required to protect the oak wood is $50 \mathrm{~kg} / \mathrm{m}^{3}$ (IBGE 2011). The wooden sleepers used by Infrabel have a rectangular cross section in the Form E1 and E2 group 2 according to EN 13145, that is $150 \mathrm{~mm}$ high by $260 \mathrm{~mm}$ wide (British Standards 2001) with a length fixed at $2600 \mathrm{~mm}$ (Infrabel 2011). Thus, the volume of a standard wooden sleeper is $0.1014 \mathrm{~m}^{3}$, resulting in a treatment with creosote of $5.07 \mathrm{~kg}$ per sleeper. By comparing with Künniger and Richter (1998), Ueda et al. (1999) and Bolin and Smith (2013), a lower quantity of concrete is considered in our study.

The rails are attached to the sleeper through a variety of techniques. The most significant components of the fastening system include the following: clips for attachment, bolts, screw spikes and base plates for wooden sleepers, and rubber pad for concrete sleepers. For concrete sleepers, six methods have been identified, and in the case of wooden sleepers, four and six methods have been identified for main and side lines, respectively (Infrabel 2007). As shown in Table 8, the average amount of representative elements for concrete and wooden sleepers in the main and side lines has been calculated.

Regarding the distribution of sleepers in the Belgian railway network, concrete sleepers constituted $79 \%$ in main lines and 35\% in side lines in the year 2010; meanwhile, wooden sleepers represented $21 \%$ and $65 \%$ in main and side lines, respectively (UIC 2013). In the case of switch and crossing systems, wooden sleepers accounted for $95 \%$ and concrete sleepers for 5\% (UIC 2013) as the wooden sleepers allow greater flexibility in making custom-made sleepers (IBGE 2011). In order to calculate the annual material demand from sleepers and fastening system of the Belgian railway network, the ratio between main and side lines from Table 9 has been used.

\section{Switch and crossing system}

The connection between the different railway lines is achieved through the construction of switches and crossings. Therefore, switch and crossing system is a fundamental component to link different transport routes and creating a railway network. The most important components included in our study are the common crossing, switch rails, outside rails, check rails and breather switch (Fig. 2).
Table 8 Material profile of some representative elements of the fastening system and average amount used in the Belgian railway network. Source: Infrabel (2007)

\begin{tabular}{|c|c|c|c|c|c|c|}
\hline & \multirow[t]{2}{*}{ Material } & \multirow{2}{*}{$\begin{array}{l}\text { Weight } \\
\text { (kg/unit) }\end{array}$} & \multirow[t]{2}{*}{ Lifespan } & \multirow{2}{*}{$\begin{array}{l}\text { Concrete sleeper } \\
\text { (unit/sleeper) }\end{array}$} & \multicolumn{2}{|c|}{ Wooden sleeper } \\
\hline & & & & & $\begin{array}{l}\text { Main track } \\
\text { (unit/sleeper) }\end{array}$ & $\begin{array}{l}\text { Side track } \\
\text { (unit/ } \\
\text { sleeper) }\end{array}$ \\
\hline Screw spike & Steel & 1.1 & $30-35$ & - & 5 & 6.5 \\
\hline Clip & Steel & 1 & $35-40$ & 4 & 4.5 & 1 \\
\hline Bolt & Steel & 0.3 & $30-35$ & 4 & 1 & 1 \\
\hline Base plate & Steel & 3.5 & 40 & - & 1.5 & 1.5 \\
\hline Rubber pad & Rubber & 0.6 & $20-25$ & 2 & - & - \\
\hline
\end{tabular}


Table 9 Ratio between main and side lines in the Belgian railway network. Source: Infrabel (2016)

\begin{tabular}{llllllll}
\hline & 2006 & 2007 & 2008 & 2009 & 2010 & 2011 & 2012 \\
\hline Main lines share (\%) & 69.2 & 69.2 & 69.5 & 72.9 & 72.6 & 71.6 & 72.1 \\
Side lines share (\%) & 30.8 & 30.8 & 30.5 & 27.1 & 27.4 & 28.4 & 27.9 \\
\hline
\end{tabular}

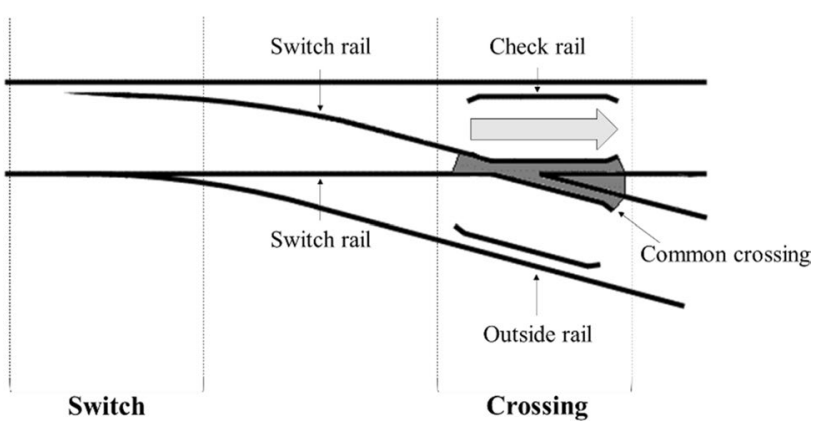

Fig. 2 Switch and crossing system

Infrabel uses three types of common crossings in the Belgian railway network (Infrabel 2007), being the ratio between monobloc, assembled and machined common crossings of $65 \%, 19 \%$ and $16 \%$, respectively. Table 10 presents the average weight of the different components per switch and crossing system. Since the lifespan of the switches is not available, the same lifespan as the rails has been considered (i.e. 30 years).

The annual material demand from switches and crossings of the Belgian railway network has been calculated using the total number of switches in the main and side lines (Table 11) and the ratio between main and side lines. Note that our study does not include the manufacturing processes of the switches and crossings.

\section{Overhead contact system}

The Belgian railway network has three major types of overhead contact systems. Most of the overhead contact lines present a $3 \mathrm{kV}$ DC power supply, of which the type compound has a length of $4330 \mathrm{~km}$ and the type R3 is $490 \mathrm{~km}$ long. The overhead high-speed lines (HSL) with a power supply of $25 \mathrm{kV} \mathrm{AC}$ are $450 \mathrm{~km}$ long. Figure 3 shows the most important components of the overhead contact lines included in our study. The overhead contact system is supported by a mast of height varying between 7 and 15 meters, to which a bracket system that holds the catenary wire is attached. The catenary wire is connected to the contact wires using droppers. The electricity supplied by the feeders is transmitted to the trains through the contact of the contact wires with the pantograph on top of the train. The support structures are isolated from the electric parts using insulators, whilst the mast is connected to an earth wire.

Table 12 shows the material composition of the overhead contact system of the Belgian railway network collected from Infrabel through the use of questionnaires.

The annual material demand due to the overhead contact line system has been calculated in three steps. Firstly, we have calculated separately the material demand of the three types of overhead contact line (i.e. compound, R3 and HSL) present in the Belgian railway network. For some components such as mast, bracket systems and insulators, it has
Table 10 Average weight and number of the different switches' elements. Source: Infrabel (2007)

Table 11 Number of switches in main and side lines in the Belgian railway network. Source: Infrabel (2016)

\begin{tabular}{lcll}
\hline Switch and crossing system elements & Weight (kg/unit) & Unit/switch & $\begin{array}{l}\text { Weight } \\
\text { (kg/ } \\
\text { switch) }\end{array}$ \\
\hline Common crossing-monobloc & 1423 & $65 \%$ & - \\
Common crossing—assembled & 588 & $19 \%$ & - \\
Common crossing-machined & 934 & $16 \%$ & - \\
Average common crossing & 1186 & 1 & 1186 \\
Average switch rail & 1373 & 2 & 2746 \\
Average outside rail & 445 & 2 & 890 \\
Average breather switch & 729 & 1 & 729 \\
Check rail & 88 & 2 & 176 \\
\hline
\end{tabular}

\begin{tabular}{llllllll}
\hline & 2006 & 2007 & 2008 & 2009 & 2010 & 2011 & 2012 \\
\hline Main lines & 4446 & 4438 & 4510 & 4526 & 4513 & 4488 & 4470 \\
Side lines & 8378 & 8161 & 7904 & 7692 & 7588 & 7519 & 7327 \\
\hline
\end{tabular}




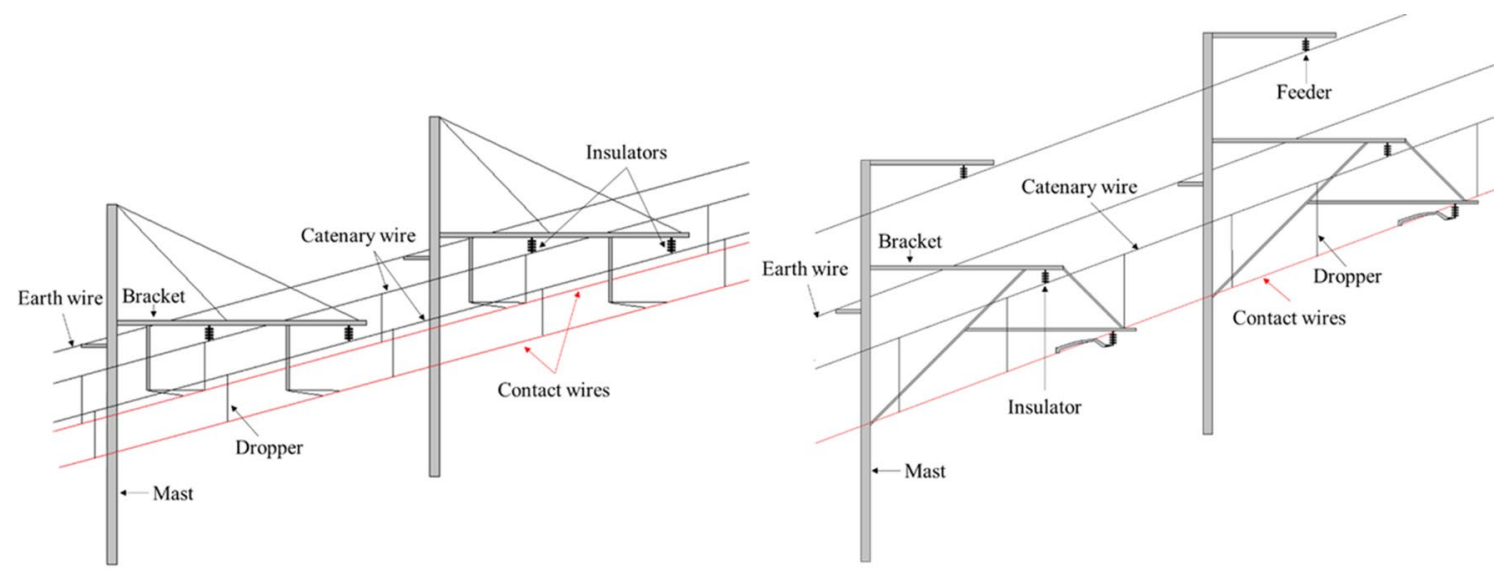

Fig. 3 Examples of overhead compound lines (left) and overhead R3 lines (right)

been calculated the average units of these components per meter of overhead contact line. Secondly, we have calculated the material demand for an average overhead contact line considering a share of $82.2 \%, 9.3 \%$ and $8.5 \%$ for the compound, R3 and HSL overhead contact lines, respectively. The components of the overhead contact system made of the same material have been grouped, such as the masts and bracket systems made of steel and the insulators made of glass fibre. Thirdly, since the Belgian railway network is not completely electrified, we have calculated the contribution of material demand from the overhead contact system for the Belgian railway network considering both electrified and non-electrified network (Table 13).

\section{$\mathrm{LCl}$ of railway construction}

Table 14 shows the LCI for the construction of an average double-track railway line in Belgium. The material demand for the track construction is considered in the complete railway network, adding the material demand for the construction of tunnels and bridges by considering their respective railway network share. The components of the same material have been grouped such as the concrete for tunnels and bridge construction and the manufacturing of concrete sleepers. Furthermore, we have included two more processes from Spielmann et al. (2007) not considered previously in the railway track construction, such as $1.2 \mathrm{~m}^{3} /(\mathrm{m} \times \mathrm{a})$ of excavation by a skid-steer loader and $0.05 \mathrm{MJ} /(\mathrm{m} \times \mathrm{a})$ of diesel.

By comparing the values obtained in our study with the values from Spielmann et al. (2007), our results for Belgium show a lower material consumption on concrete (high exacting) and reinforcing steel. Moreover, a lower energy consumption on diesel and electricity is obtained in our research as a result of both the lower energy consumption in the tunnel construction and the lower share of tunnel in the railway network considered in our study compared to Spielmann et al. (2007). Furthermore, our results for the Belgian railway infrastructure present a higher material consumption on gravel, steel (low-alloyed) and aluminium. Note that our LCI for the railway construction presents a larger number of elements such as wood, creosote and rubber pad from the sleeper system and other materials from the overhead contact system.

\section{Railway maintenance}

For the maintenance of the Belgian railway infrastructure, we have considered both the renewal of materials such as rails, sleepers, switches and crossings, and ballast and the maintenance works such as rail grinding, ballast tamping, ballast profiling, ballast stabilization, ballast cleaning and weed control. Hence, we have included both the diesel consumption and exhaust emissions from the maintenance equipment and the new components for the renewal of tracks. Table 15 shows the maintenance works in the Belgian railway network.

Table 16 presents the LCI of the Belgian railway infrastructure maintenance. An electricity consumption from ventilation of tunnel operation of $837 \mathrm{kWh} /(\mathrm{m} \times \mathrm{a})$ has been considered (Spielmann et al. 2007), which has been multiplied by the tunnel share of every year.

\section{Maintenance of rails}

The steel demand of the rails renewal has been calculated using the kilometres per year of rail removed from Infrabel and the previously calculated $7.3 \mathrm{~kg} /(\mathrm{m} \times \mathrm{a})$ of steel from rails in the railway infrastructure construction. The diesel consumption of the rail laying machine used in the rail renewal has been calculated using a construction speed of $37 \mathrm{~h} / \mathrm{km}$ and a diesel consumption of $5 \mathrm{~L} / \mathrm{h}$ from Kiani et al. (2008). 
Table 12 Material composition of the overhead contact system of the Belgian railway network. Source: Infrabel (2016)

\begin{tabular}{|c|c|c|c|c|c|c|c|}
\hline OCL type & Component & Material & Unit & Belgium & Lifespan & Average unit $/ \mathrm{km}$ & Additional data \\
\hline \multirow{2}{*}{$\begin{array}{l}\text { Compound-R3- } \\
\text { HSL }\end{array}$} & \multirow[t]{2}{*}{ Mast } & Steel & $\mathrm{kg} / \mathrm{unit}$ & 830 & 60 & \multirow[t]{2}{*}{45} & \multirow{2}{*}{$\begin{array}{l}\text { Depending on the } \\
\text { length and section }\end{array}$} \\
\hline & & Zinc & $\mathrm{kg} / \mathrm{unit}$ & Negligible & $20-40$ & & \\
\hline Compound & Bracket system & Galvanized steel & $\mathrm{kg} / \mathrm{unit}$ & 20 & 60 & 45 & \multirow{2}{*}{$\begin{array}{l}\text { Depending on the } \\
\text { bracket length }\end{array}$} \\
\hline R3-HSL & Bracket system & $\mathrm{Al}$ & $\mathrm{kg}$ /unit & 35 & 60 & 45 & \\
\hline \multirow[t]{4}{*}{ Compound } & $\begin{array}{l}\text { Contact wire } \\
107 \mathrm{~mm}^{2}\end{array}$ & $\mathrm{Cu} \mathrm{Ag}$ & $\mathrm{kg} / \mathrm{m}$ & 0.951 & 15 & 2 wires & Weight varies $\pm 3 \%$ \\
\hline & $\begin{array}{l}\text { Main catenary wire } \\
95 \mathrm{~mm}^{2}\end{array}$ & $\mathrm{Cu} \mathrm{Cd} \mathrm{Sn}$ & $\mathrm{kg} / \mathrm{m}$ & 0.855 & 60 & 1 wire & Weight varies to $+4 \%$ \\
\hline & $\begin{array}{l}\text { Auxiliary catenary } \\
\text { wire } 104 \mathrm{~mm}^{2}\end{array}$ & $\mathrm{Cu} \mathrm{Cd} \mathrm{Sn}$ & $\mathrm{kg} / \mathrm{m}$ & 0.924 & 60 & 1 wire & - \\
\hline & Earth wire $75 \mathrm{~mm}^{2}$ & Almelec ${ }^{\mathrm{a}}$ & $\mathrm{kg} / \mathrm{m}$ & 0.213 & 60 & 1 wire & - \\
\hline \multirow[t]{4}{*}{ R3 } & $\begin{array}{l}\text { Contact wire } \\
120 \mathrm{~mm}^{2}\end{array}$ & $\mathrm{Cu} \mathrm{Ag}$ & $\mathrm{kg} / \mathrm{m}$ & 1.067 & 20 & 2 wires & Weight varies $\pm 3 \%$ \\
\hline & $\begin{array}{l}\text { Catenary wire } \\
95 \mathrm{~mm}^{2}\end{array}$ & $\mathrm{Cu}$ Cd Sn & $\mathrm{kg} / \mathrm{m}$ & 0.855 & 60 & 1 wire & Weight varies to $+4 \%$ \\
\hline & Feeder $366 \mathrm{~mm}^{2}$ & Almelec $^{\mathrm{a}}$ & $\mathrm{kg} / \mathrm{m}$ & 1.051 & 60 & 1 wire & - \\
\hline & Earth wire $75 \mathrm{~mm}^{2}$ & Almelec $^{\mathrm{a}}$ & $\mathrm{kg} / \mathrm{m}$ & 0.213 & 60 & 1 wire & - \\
\hline \multirow[t]{5}{*}{ HSL } & $\begin{array}{l}\text { Contact wire } \\
150 \mathrm{~mm}^{2}\end{array}$ & $\mathrm{Cu} \mathrm{Mg}$ & $\mathrm{kg} / \mathrm{m}$ & 1.333 & 25 & 1 wire & Weight varies $\pm 3 \%$ \\
\hline & $\begin{array}{l}\text { Catenary wire } \\
95 \mathrm{~mm}^{2}\end{array}$ & $\mathrm{Cu} \mathrm{Cd}$ or $\mathrm{Cu} \mathrm{Mn}$ & $\mathrm{kg} / \mathrm{m}$ & 0.830 & 60 & 1 wire & - \\
\hline & Feeder $288 \mathrm{~mm}^{2}$ & Almelec $^{\mathrm{a}}$ & $\mathrm{kg} / \mathrm{m}$ & 0.828 & 60 & 1 wire & - \\
\hline & $\begin{array}{l}\text { Aerial earth wire } \\
117 \mathrm{~mm}^{2}\end{array}$ & Almelec ${ }^{\mathrm{a}}$ & $\mathrm{kg} / \mathrm{m}$ & 0.330 & 60 & 1 wire & - \\
\hline & $\begin{array}{l}\text { Underground earth } \\
\text { wire } 35 \mathrm{~mm}^{2}\end{array}$ & $\mathrm{Cu}$ & $\mathrm{kg} / \mathrm{m}$ & 0.311 & 60 & 1 wire & - \\
\hline Compound-R3 & Suspension insulators & Fixation: steel or Al & $\mathrm{kg} / \mathrm{unit}$ & 1.4 & 30 & 45 & - \\
\hline Compound & $\begin{array}{l}\text { Insulator of registra- } \\
\text { tion arm }\end{array}$ & Body: glass fibre & $\mathrm{kg}$ /unit & 2.44 & 30 & 45 & - \\
\hline R3 & $\begin{array}{l}\text { Insulator of registra- } \\
\text { tion arm }\end{array}$ & & $\mathrm{kg} / \mathrm{unit}$ & 3.85 & 30 & 45 & - \\
\hline R3 & $\begin{array}{l}\text { Suspension insulators } \\
\text { Feeder }\end{array}$ & & $\mathrm{kg} / \mathrm{unit}$ & 1.4 & 30 & 45 & - \\
\hline HSL & Bracket insulators & & $\mathrm{kg} / \mathrm{unit}$ & 5.9 & 30 & 85 & - \\
\hline HSL & $\begin{array}{l}\text { Suspension insulators } \\
\text { Feeder }\end{array}$ & & $\mathrm{kg} / \mathrm{unit}$ & 1.71 & 30 & 45 & - \\
\hline- & Compact insulators $^{\mathrm{b}}$ & Glass fibre and $\mathrm{Cu}$ & $\mathrm{kg}$ /unit & 60 & 30 & 0.83 & - \\
\hline
\end{tabular}

${ }^{a}$ Aluminium alloy with small proportions of magnesium and silicon

${ }^{\mathrm{b}}$ Approximately 5000 units in an electrified network of $6000 \mathrm{~km}$

Table 13 Length of the tracks in the Belgian railway network. Source: Eurostat statistics (2017)

\begin{tabular}{lrllr}
\hline & 2006 & 2007 & 2008 & 2009 \\
\hline Electrified tracks (km) & 5462 & 5454 & 5601 & 5661 \\
Non-electrified tracks (km) & 605 & 507 & 682 & 775 \\
Electrified tracks share (\%) & 90 & 91.5 & 89.2 & 88 \\
Non-electrified tracks share (\%) & 10 & 8.5 & 10.8 & 12 \\
\hline
\end{tabular}

Rail grinding is a maintenance process to improve the rail surface. It avoids a further deterioration of the rails, removing the surface corrosion, deformities and damages from the rail and restoring the rail profile (Krezo et al. 2016), which reduces the iron abrasion of the rails and wheels and enhances the quality of the ride, and it reduces the noise emissions from rail transport. Rail grinding produces particle emissions from both the rail and the grinding stone. Moreover, the exhaust emissions and energy consumption of the vehicle and the water consumed for collecting the grinding particles have to be considered (Barton et al. 2010). 


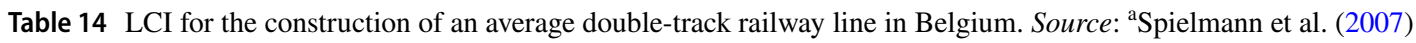

\begin{tabular}{|c|c|c|c|c|c|c|c|c|}
\hline & 2006 & 2007 & 2008 & 2009 & 2010 & 2011 & 2012 & Switzerland $^{\mathrm{a}}$ \\
\hline Concrete, high exacting $\left(\mathrm{m}^{3} /(\mathrm{m} \times \mathrm{a})\right)$ & $3.00 \times 10^{-2}$ & $2.99 \times 10^{-2}$ & $3.02 \times 10^{-2}$ & $3.01 \times 10^{-2}$ & $3.00 \times 10^{-2}$ & $3.00 \times 10^{-2}$ & $3.00 \times 10^{-2}$ & $4.31 \times 10^{-2}$ \\
\hline Reinforcing steel $(\mathrm{kg} /(\mathrm{m} \times \mathrm{a}))$ & 11.33 & 11.31 & 11.32 & 11.31 & 11.30 & 11.29 & 11.28 & 13.5 \\
\hline Wood $(\mathrm{kg} /(\mathrm{m} \times \mathrm{a}))$ & 3.26 & 3.26 & 3.25 & 3.14 & 3.15 & 3.18 & 3.16 & - \\
\hline Creosote $(\mathrm{kg} /(\mathrm{m} \times \mathrm{a}))$ & $2.07 \times 10^{-1}$ & $2.07 \times 10^{-1}$ & $2.06 \times 10^{-1}$ & $1.99 \times 10^{-1}$ & $1.99 \times 10^{-1}$ & $2.01 \times 10^{-1}$ & $2.00 \times 10^{-1}$ & - \\
\hline Rubber pad $(\mathrm{kg} /(\mathrm{m} \times \mathrm{a}))$ & $1.27 \times 10^{-1}$ & $1.27 \times 10^{-1}$ & $1.27 \times 10^{-1}$ & $1.30 \times 10^{-1}$ & $1.30 \times 10^{-1}$ & $1.29 \times 10^{-1}$ & $1.30 \times 10^{-1}$ & - \\
\hline Gravel, crushed $(\mathrm{kg} /(\mathrm{m} \times \mathrm{a}))$ & 708.06 & 708.02 & 708.27 & 707.98 & 707.96 & 707.94 & 707.92 & 571 \\
\hline Steel, low-alloyed $(\mathrm{kg} /(\mathrm{m} \times \mathrm{a}))$ & 1.14 & 1.16 & 1.13 & 1.12 & - & - & - & $5.60 \times 10^{-1}$ \\
\hline $\mathrm{Al}(\mathrm{kg} /(\mathrm{m} \times \mathrm{a}))$ & $8.43 \times 10^{-3}$ & $8.57 \times 10^{-3}$ & $8.35 \times 10^{-3}$ & $8.24 \times 10^{-3}$ & - & - & - & $6.00 \times 10^{-3}$ \\
\hline $\mathrm{CuAg}(\mathrm{kg} /(\mathrm{m} \times \mathrm{a}))$ & $2.05 \times 10^{-1}$ & $2.09 \times 10^{-1}$ & $2.03 \times 10^{-1}$ & $2.01 \times 10^{-1}$ & - & - & - & $5.50 \times 10^{-2}$ \\
\hline $\mathrm{CuMg}(\mathrm{kg} /(\mathrm{m} \times \mathrm{a}))$ & $8.20 \times 10^{-3}$ & $8.33 \times 10^{-3}$ & $8.12 \times 10^{-3}$ & $8.01 \times 10^{-3}$ & - & - & - & - \\
\hline $\mathrm{CuCdSn}(\mathrm{kg} /(\mathrm{m} \times \mathrm{a}))$ & $4.62 \times 10^{-2}$ & $4.70 \times 10^{-2}$ & $4.58 \times 10^{-2}$ & $4.52 \times 10^{-2}$ & - & - & - & - \\
\hline $\operatorname{CuMn}(\mathrm{kg} /(\mathrm{m} \times \mathrm{a}))$ & $2.13 \times 10^{-3}$ & $2.16 \times 10^{-3}$ & $2.11 \times 10^{-3}$ & $2.08 \times 10^{-3}$ & - & - & - & - \\
\hline Almelec $(\mathrm{kg} /(\mathrm{m} \times \mathrm{a}))$ & $1.17 \times 10^{-2}$ & $1.19 \times 10^{-2}$ & $1.16 \times 10^{-2}$ & $1.15 \times 10^{-2}$ & - & - & - & - \\
\hline $\mathrm{Cu}(\mathrm{kg} /(\mathrm{m} \times \mathrm{a}))$ & $7.17 \times 10^{-5}$ & $7.29 \times 10^{-5}$ & $7.10 \times 10^{-5}$ & $7.01 \times 10^{-5}$ & - & - & - & - \\
\hline Glass fibre $(\mathrm{kg} /(\mathrm{m} \times \mathrm{a}))$ & $1.66 \times 10^{-2}$ & $1.68 \times 10^{-2}$ & $1.64 \times 10^{-2}$ & $1.62 \times 10^{-2}$ & - & - & - & - \\
\hline Excavation soil $\left(\mathrm{m}^{3} /(\mathrm{m} \times \mathrm{a})\right)$ & $7.99 \times 10^{-2}$ & $7.98 \times 10^{-2}$ & $8.10 \times 10^{-2}$ & $7.96 \times 10^{-2}$ & $7.95 \times 10^{-2}$ & $7.94 \times 10^{-2}$ & $7.93 \times 10^{-2}$ & 340 \\
\hline Excavation $\left(\mathrm{m}^{3} /(\mathrm{m} \times \mathrm{a})\right.$ & 1.20 & 1.20 & 1.20 & 1.20 & 1.20 & 1.20 & 1.20 & 1.20 \\
\hline Diesel $(\mathrm{MJ} /(\mathrm{m} \times \mathrm{a}))$ & 2.22 & 2.21 & 2.240 & 2.21 & 2.20 & 2.20 & 2.20 & 9.50 \\
\hline Electricity $(\mathrm{kWh} /(\mathrm{m} \times \mathrm{a}))$ & $7.89 \times 10^{-1}$ & $7.88 \times 10^{-1}$ & $8.00 \times 10^{-1}$ & $7.85 \times 10^{-1}$ & $7.85 \times 10^{-1}$ & $7.84 \times 10^{-1}$ & $7.82 \times 10^{-1}$ & 3.98 \\
\hline
\end{tabular}

Table 15 Maintenance works in the Belgian railway network. Source: Infrabel (2016)

\begin{tabular}{lrrrrrrr}
\hline & 2006 & 2007 & 2008 & 2009 & 2010 & 2011 & 2012 \\
\hline Rails renewal in main lines (km/year) & 61 & 100 & 140 & 212 & 99 & 121 & 119 \\
Sleepers renewal in main lines (km/year) & 147 & 171 & 170 & 150 & 175 & 90 & 110 \\
Switches renewal (units) & 62 & 86 & 100 & 82 & 62 & 65 & 72 \\
Ballast renewal (km/year) & 59 & 96 & 110 & 115 & 59 & 31 & 22 \\
\hline
\end{tabular}

In the year 2014, a length of $1038 \mathrm{~km}$ of the Belgian railway network was rail-grinded. Since we consider a regular rail grinding schedule (Milford and Allwood 2010), we have used this value for every year. Note that there are higher amount of kilometres of rail grinding every year in the railway network compared with other maintenance works. This results in a great energy consumption from this maintenance process. Thereby, most of the diesel consumption from the maintenance works is due to rail grinding.

\section{Maintenance of sleepers}

The material demand of the sleeper renewal has been calculated using the kilometres per year of sleeper removed in main lines from Infrabel. Moreover, the previously calculated material demand of concrete $(9.42 \mathrm{~kg} /(\mathrm{m} \times \mathrm{a}))$ and steel $(0.26 \mathrm{~kg} /(\mathrm{m} \times \mathrm{a}))$ from concrete sleepers and oak wood $(1.12 \mathrm{~kg} /(\mathrm{m} \times \mathrm{a}))$ and creosote $(0.07 \mathrm{~kg} /(\mathrm{m} \times \mathrm{a}))$ from wooden sleepers (considering a ratio between wooden and concrete sleepers in the main tracks of $21 \%$ and $79 \%$, 
Table 16 Material demand for the railway maintenance of an average Belgian double-track railway line

\begin{tabular}{|c|c|c|c|c|c|c|c|c|}
\hline Maintenance & $\begin{array}{l}\text { Material or energy } \\
\text { source }\end{array}$ & 2006 & 2007 & 2008 & 2009 & 2010 & 2011 & 2012 \\
\hline Tunnel ventilation & Electricity $(\mathrm{kWh} /(\mathrm{m} \times \mathrm{a})$ & 22.34 & 22.29 & 22.63 & 22.22 & 22.20 & 22.17 & 22.14 \\
\hline \multirow[t]{2}{*}{$\begin{array}{l}\text { Rail and splice bar } \\
\text { renewal }\end{array}$} & $\begin{array}{l}\text { Reinforcing steel }(\mathrm{kg} / \\
(\mathrm{m} \times \mathrm{a}))\end{array}$ & $7.07 \times 10^{-2}$ & $1.16 \times 10^{-1}$ & $1.63 \times 10^{-1}$ & $2.43 \times 10^{-1}$ & $1.12 \times 10^{-1}$ & $1.37 \times 10^{-1}$ & $1.34 \times 10^{-1}$ \\
\hline & Diesel $(\mathrm{MJ} /(\mathrm{m} \times \mathrm{a}))$ & $1.29 \times 10^{-1}$ & $2.11 \times 10^{-1}$ & $2.96 \times 10^{-1}$ & $4.43 \times 10^{-1}$ & $2.04 \times 10^{-1}$ & $2.49 \times 10^{-1}$ & $2.44 \times 10^{-1}$ \\
\hline \multirow[t]{2}{*}{ Rail grinding } & Diesel $(\mathrm{MJ} /(\mathrm{m} \times \mathrm{a}))$ & 9.41 & 9.39 & 9.43 & 9.31 & 9.19 & 9.15 & 9.12 \\
\hline & Water $(\mathrm{L} /(\mathrm{m} \times \mathrm{a}))$ & $1.65 \times 10^{-1}$ & $1.65 \times 10^{-1}$ & $1.65 \times 10^{-1}$ & $1.63 \times 10^{-1}$ & $1.61 \times 10^{-1}$ & $1.60 \times 10^{-1}$ & $1.60 \times 10^{-1}$ \\
\hline \multirow{5}{*}{$\begin{array}{l}\text { Sleeper renewal-sleep- } \\
\text { ers }\end{array}$} & Concrete $\left(\mathrm{m}^{3} /(\mathrm{m} \times \mathrm{a})\right)$ & $1.80 \times 10^{-4}$ & $2.09 \times 10^{-4}$ & $2.09 \times 10^{-4}$ & $1.82 \times 10^{-4}$ & $2.10 \times 10^{-4}$ & $1.07 \times 10^{-4}$ & $1.31 \times 10^{-4}$ \\
\hline & $\begin{array}{l}\text { Reinforcing steel }(\mathrm{kg} / \\
(\mathrm{m} \times \mathrm{a}))\end{array}$ & $1.20 \times 10^{-2}$ & $1.39 \times 10^{-2}$ & $1.39 \times 10^{-2}$ & $1.21 \times 10^{-2}$ & $1.40 \times 10^{-2}$ & $7.14 \times 10^{-3}$ & $8.70 \times 10^{-3}$ \\
\hline & Wood $(\mathrm{kg} /(\mathrm{m} \times \mathrm{a}))$ & $5.23 \times 10^{-2}$ & $6.07 \times 10^{-2}$ & $6.06 \times 10^{-2}$ & $5.28 \times 10^{-2}$ & $6.09 \times 10^{-2}$ & $3.12 \times 10^{-2}$ & $3.79 \times 10^{-2}$ \\
\hline & Creosote $(\mathrm{kg} /(\mathrm{m} \times \mathrm{a}))$ & $3.32 \times 10^{-3}$ & $3.85 \times 10^{-3}$ & $3.84 \times 10^{-3}$ & $3.35 \times 10^{-3}$ & $3.86 \times 10^{-3}$ & $1.98 \times 10^{-3}$ & $2.40 \times 10^{-3}$ \\
\hline & Diesel $(\mathrm{MJ} /(\mathrm{m} \times \mathrm{a}))$ & $1.18 \times 10^{-1}$ & $1.36 \times 10^{-1}$ & $1.36 \times 10^{-1}$ & $1.19 \times 10^{-1}$ & $1.37 \times 10^{-1}$ & $7.00 \times 10^{-2}$ & $8.52 \times 10^{-2}$ \\
\hline \multirow[t]{2}{*}{$\begin{array}{l}\text { Sleeper renewal-fasten- } \\
\text { ing system }\end{array}$} & $\begin{array}{l}\text { Reinforcing steel }(\mathrm{kg} / \\
(\mathrm{m} \times \mathrm{a}))\end{array}$ & $1.69 \times 10^{-2}$ & $1.96 \times 10^{-2}$ & $1.96 \times 10^{-2}$ & $1.71 \times 10^{-2}$ & $1.97 \times 10^{-2}$ & $1.01 \times 10^{-2}$ & $1.23 \times 10^{-2}$ \\
\hline & Rubber pad $(\mathrm{kg} /(\mathrm{m} \times \mathrm{a}))$ & $3.69 \times 10^{-3}$ & $4.28 \times 10^{-3}$ & $4.28 \times 10^{-3}$ & $3.73 \times 10^{-3}$ & $4.29 \times 10^{-3}$ & $2.20 \times 10^{-3}$ & $2.68 \times 10^{-3}$ \\
\hline \multirow[t]{3}{*}{$\begin{array}{l}\text { Switches and crossings } \\
\text { renewal }\end{array}$} & $\begin{array}{l}\text { Reinforcing steel }(\mathrm{kg} / \\
(\mathrm{m} \times \mathrm{a}))\end{array}$ & $3.76 \times 10^{-3}$ & $5.21 \times 10^{-3}$ & $6.08 \times 10^{-3}$ & $4.92 \times 10^{-3}$ & $3.67 \times 10^{-3}$ & $3.84 \times 10^{-3}$ & $4.23 \times 10^{-3}$ \\
\hline & Electricity $(\mathrm{kWh} /(\mathrm{m} \times \mathrm{a}))$ & 1.13 & 1.12 & 1.09 & 1.11 & 1.09 & 1.07 & 1.05 \\
\hline & $\begin{array}{l}\text { Lubricating oil }(\mathrm{kg} / \\
\quad(\mathrm{m} \times \mathrm{a}))\end{array}$ & $9.25 \times 10^{-3}$ & $9.11 \times 10^{-3}$ & $8.89 \times 10^{-3}$ & $9.02 \times 10^{-3}$ & $8.89 \times 10^{-3}$ & $8.69 \times 10^{-3}$ & $8.57 \times 10^{-3}$ \\
\hline \multirow[t]{5}{*}{ Ballast renewal } & $\begin{array}{l}\text { Gravel, crushed }(\mathrm{kg} / \\
\quad(\mathrm{m} \times \mathrm{a}))\end{array}$ & 1.50 & 2.44 & 2.80 & 2.89 & 1.47 & $7.67 \times 10^{-1}$ & $5.42 \times 10^{-1}$ \\
\hline & $\begin{array}{l}\text { Ballast spreading } \\
\text { machine }(\mathrm{MJ} /(\mathrm{m} \times \mathrm{a}))\end{array}$ & $8.09 \times 10^{-2}$ & $1.31 \times 10^{-1}$ & $1.51 \times 10^{-1}$ & $1.56 \times 10^{-1}$ & $7.90 \times 10^{-2}$ & $4.13 \times 10^{-2}$ & $2.92 \times 10^{-2}$ \\
\hline & $\begin{array}{l}\text { Ballast tamping machine } \\
(\mathrm{MJ} /(\mathrm{m} \times \mathrm{a}))\end{array}$ & $3.23 \times 10^{-1}$ & $5.25 \times 10^{-1}$ & $6.04 \times 10^{-1}$ & $6.24 \times 10^{-1}$ & $3.16 \times 10^{-1}$ & $1.65 \times 10^{-1}$ & $1.17 \times 10^{-1}$ \\
\hline & $\begin{array}{l}\text { Ballast changing machine } \\
(\mathrm{MJ} /(\mathrm{m} \times \mathrm{a}))\end{array}$ & $1.72 \times 10^{-1}$ & $2.79 \times 10^{-1}$ & $3.21 \times 10^{-1}$ & $3.32 \times 10^{-1}$ & $1.68 \times 10^{-1}$ & $8.79 \times 10^{-2}$ & $6.21 \times 10^{-2}$ \\
\hline & $\begin{array}{l}\text { Ballast cleaning machine } \\
(\mathrm{MJ} /(\mathrm{m} \times \mathrm{a}))\end{array}$ & $1.72 \times 10^{-1}$ & $2.79 \times 10^{-1}$ & $3.21 \times 10^{-1}$ & $3.32 \times 10^{-1}$ & $1.68 \times 10^{-1}$ & $8.79 \times 10^{-2}$ & $6.21 \times 10^{-2}$ \\
\hline \multirow[t]{8}{*}{ Weed control } & Glyphosate $(\mathrm{kg} /(\mathrm{m} \times \mathrm{a}))$ & 1.41 & 1.41 & 1.41 & 1.39 & 1.38 & 1.37 & 1.37 \\
\hline & Clopyralide $(\mathrm{kg} /(\mathrm{m} \times \mathrm{a}))$ & $2.99 \times 10^{-3}$ & $2.98 \times 10^{-3}$ & $2.99 \times 10^{-3}$ & $2.96 \times 10^{-3}$ & $2.92 \times 10^{-3}$ & $2.91 \times 10^{-3}$ & $2.89 \times 10^{-3}$ \\
\hline & Fluroxypyr $(\mathrm{kg} /(\mathrm{m} \times \mathrm{a}))$ & $5.97 \times 10^{-3}$ & $5.96 \times 10^{-3}$ & $5.99 \times 10^{-3}$ & $5.91 \times 10^{-3}$ & $5.84 \times 10^{-3}$ & $5.81 \times 10^{-3}$ & $5.79 \times 10^{-3}$ \\
\hline & $\operatorname{MCPA}(\mathrm{kg} /(\mathrm{m} \times \mathrm{a}))$ & $1.77 \times 10^{-1}$ & $1.77 \times 10^{-1}$ & $1.77 \times 10^{-1}$ & $1.75 \times 10^{-1}$ & $1.73 \times 10^{-1}$ & $1.72 \times 10^{-1}$ & $1.72 \times 10^{-1}$ \\
\hline & Diflufenican $(\mathrm{kg} /(\mathrm{m} \times \mathrm{a}))$ & $8.17 \times 10^{-2}$ & $8.15 \times 10^{-2}$ & $8.18 \times 10^{-2}$ & $8.08 \times 10^{-2}$ & $7.98 \times 10^{-2}$ & $7.94 \times 10^{-2}$ & $7.91 \times 10^{-2}$ \\
\hline & Triclopyr $(\mathrm{kg} /(\mathrm{m} \times \mathrm{a}))$ & $2.38 \times 10^{-1}$ & $2.37 \times 10^{-1}$ & $2.38 \times 10^{-1}$ & $2.35 \times 10^{-1}$ & $2.32 \times 10^{-1}$ & $2.31 \times 10^{-1}$ & $2.30 \times 10^{-1}$ \\
\hline & $2,4 \mathrm{D}(\mathrm{kg} /(\mathrm{m} \times \mathrm{a}))$ & $3.55 \times 10^{-1}$ & $3.54 \times 10^{-1}$ & $3.55 \times 10^{-1}$ & $3.51 \times 10^{-1}$ & $3.46 \times 10^{-1}$ & $3.45 \times 10^{-1}$ & $3.44 \times 10^{-1}$ \\
\hline & $\begin{array}{l}\text { Flazasulfuron }(\mathrm{kg} / \\
(\mathrm{m} \times \mathrm{a}))\end{array}$ & $1.10 \times 10^{-2}$ & $1.09 \times 10^{-2}$ & $1.10 \times 10^{-2}$ & $1.08 \times 10^{-2}$ & $1.07 \times 10^{-2}$ & $1.07 \times 10^{-2}$ & $1.06 \times 10^{-2}$ \\
\hline
\end{tabular}

respectively) in the railway infrastructure construction has been used.

The material demand of the fastening system used to fix the rail to the sleepers in the main lines has been calculated. The previously calculated material demand from clips $(0.15 \mathrm{~kg} /(\mathrm{m} \times \mathrm{a}))$, bolts $(0.05 \mathrm{~kg} /(\mathrm{m} \times \mathrm{a}))$ and rubber pads $(0.08 \mathrm{~kg} /(\mathrm{m} \times \mathrm{a}))$ from concrete sleepers and screw spikes $(0.06 \mathrm{~kg} /(\mathrm{m} \times \mathrm{a}))$, clips $(0.05 \mathrm{~kg} /(\mathrm{m} \times \mathrm{a}))$, bolts $(0.004 \mathrm{~kg} /(\mathrm{m} \times \mathrm{a}))$ and base plates $(0.05 \mathrm{~kg} /(\mathrm{m} \times \mathrm{a}))$ from wooden sleepers (considering a ratio between wooden and concrete sleepers in the main tracks of $21 \%$ and $79 \%$, respectively) in the railway infrastructure construction has been used.

The diesel consumption from the machinery used in the sleeper renewal has been calculated using a construction speed of $14 \mathrm{~h} / \mathrm{km}$ and a diesel consumption of $5 \mathrm{~L} / \mathrm{h}$ from Kiani et al. (2008). 


\section{Maintenance of switches and crossings}

The material demand of the switch and crossing renewal has been calculated using the unit per year of switches and crossings removed in main and side lines and an average weight of $5727 \mathrm{~kg} /$ unit of steel from switches and crossings. An electricity consumption of $400 \mathrm{kWh} / \mathrm{switch}$ per year for heating switches and a lubricating oil consumption of 3.88 $\mathrm{L} / \mathrm{switch}$ per year have been considered (Spielmann et al. 2007). The distribution per metre of switches has been used to obtain the electricity and lubricating demand from switch and crossing system of main and side lines in the Belgian railway network. Moreover, we have used the ratio between main and side lines to calculate the annual electricity and lubricating oil demand of the complete Belgian railway network.

\section{Maintenance of ballast}

The ballast demand of the ballast maintenance has been calculated using the $\mathrm{km}$ per year of ballast removed from Infrabel and a ballast consumption of $160 \mathrm{~kg} /(\mathrm{m} \times \mathrm{a})$ from the upper base. The diesel consumption from the machinery used in the ballast maintenance has been calculated using

Table 17 Use of herbicides for weed control in main tracks in 2016 and side tracks in 2015. Source: Infrabel (2016)

\begin{tabular}{lll}
\hline Herbicide & Main tracks $(\mathrm{kg})$ & $\begin{array}{l}\text { Secondary } \\
\text { tracks }(\mathrm{kg})\end{array}$ \\
\hline Glyphosate & 262 & 4173 \\
Clopyralide & - & 9.4 \\
Fluroxypyr & - & 18.8 \\
MCPA & - & 557 \\
Diflufenican & 42 & 215 \\
Triclopyr & 332 & 416 \\
2,4 D & 298 & 818 \\
Flazasulfuron & 7.5 & - \\
\hline
\end{tabular}

data from Kiani et al. (2008). Four processes have been considered in the ballast maintenance: ballast spreading with a construction speed of $12 \mathrm{~h} / \mathrm{km}$ and a diesel consumption of $10 \mathrm{~L} / \mathrm{h}$, ballast tamping with a construction speed of $32 \mathrm{~h} /$ $\mathrm{km}$ and a diesel consumption of $15 \mathrm{~L} / \mathrm{h}$, and ballast changing and ballast cleaning with a construction speed of $17 \mathrm{~h} /$ $\mathrm{km}$ and a diesel consumption of $15 \mathrm{~L} / \mathrm{h}$ (Kiani et al. 2008).

\section{Weed control}

Table 17 shows the herbicides used for weed control in the Belgian railway network for main tracks in 2016 and secondary tracks such as tracks in stations and industrial lines in 2015. The weed control is made using a spray train in main tracks. The total length usually sprayed (two campaigns) is $7131 \mathrm{~km}$ with a surface usually treated (two campaigns) of $1200 \mathrm{ha}$. The weed control is performed by different contractors applying different chemicals.

\section{Results}

The LCIA of rail freight transport in Belgium is calculated including the life cycle stages of rail transport operation, rail equipment and rail infrastructure described above for each year.

Table 18 presents the results obtained in the LCIA of $1 \mathrm{tkm}$ of freight transported by diesel trains (including shunting activity) in Belgium. The year 2009 presents the maximum impact in all the indicators mainly because this year presents the highest energy consumption for diesel trains $(804 \mathrm{~kJ} / \mathrm{tkm})$. Note that there are no significant differences in terms of impact among the years 2006, 2007 and 2008.

Table 19 shows the results obtained in the LCIA of $1 \mathrm{tkm}$ of freight transported by electric trains in Belgium. The year 2009 presents the maximum impact in most of the indicators mainly because this year presents high energy consumption for electric trains $(547 \mathrm{~kJ} / \mathrm{tkm})$.

Table 18 LCIA of $1 \mathrm{tkm}$ transported by diesel trains in Belgium

\begin{tabular}{|c|c|c|c|c|c|c|c|c|}
\hline Impact & Unit & 2006 & 2007 & 2008 & 2009 & 2010 & 2011 & 2012 \\
\hline limate & $\mathrm{kg} \mathrm{CO}_{2}$ eq & $8.38 \times 10^{-2}$ & $8.03 \times 10^{-2}$ & $8.59 \times 10^{-2}$ & $9.72 \times 10^{-2}$ & $9.14 \times 10^{-2}$ & $7.72 \times 10^{-2}$ & $8.32 \times 10^{-2}$ \\
\hline zone depletion & kg CFC-11 eq & $1.44 \times 10^{-8}$ & $1.38 \times 10^{-8}$ & $1.48 \times 10^{-8}$ & $1.63 \times 10^{-8}$ & $1.55 \times 10^{-8}$ & $1.29 \times 10^{-8}$ & $1.38 \times 10^{-8}$ \\
\hline $\operatorname{artic}$ & $\mathrm{kg} \mathrm{PN}$ & $5.62 \times 10^{-5}$ & $5.41 \times 10^{-5}$ & $5.74 \times 10^{-5}$ & $6.70 \times 10^{-5}$ & $6.28 \times 10^{-5}$ & $5.43 \times 10^{-5}$ & $5.89 \times 10^{-5}$ \\
\hline onizing radiation $\mathrm{HH}$ & $\mathrm{kBq} \mathrm{U}$ & $7.04 \times 10^{-3}$ & $6.82 \times 10^{-3}$ & $7.23 \times 10^{-3}$ & $8.20 \times 10^{-3}$ & $7.80 \times 10^{-3}$ & $6.82 \times 10^{-3}$ & $7.27 \times 10^{-3}$ \\
\hline Photochemical ozone formation & $\mathrm{kg}$ NMVOC eq & $1.18 \times 10^{-3}$ & $1.12 \times 10^{-3}$ & $1.21 \times 10^{-3}$ & $1.32 \times 10^{-3}$ & $1.25 \times 10^{-3}$ & $1.02 \times 10^{-3}$ & $1.09 \times 10^{-3}$ \\
\hline Acidi & molc $\mathrm{I}$ & $9.59 \times 10^{-4}$ & $9.14 \times 10^{-4}$ & $9.83 \times 10^{-4}$ & $1.10 \times 10^{-3}$ & $1.03 \times 10^{-3}$ & $8.59 \times 10^{-4}$ & $9.25 \times 10^{-4}$ \\
\hline Terrestrial eutrop & molc $\mathrm{N}$ eq & $4.43 \times 10^{-3}$ & $4.20 \times 10^{-3}$ & $4.55 \times 10^{-3}$ & $4.96 \times 10^{-3}$ & $4.68 \times 10^{-3}$ & $3.80 \times 10^{-3}$ & $4.07 \times 10^{-3}$ \\
\hline Freshwater eut & $\mathrm{kg} \mathrm{P} \mathrm{eq}$ & $1.28 \times 10^{-5}$ & $1.28 \times 10^{-5}$ & $1.31 \times 10^{-5}$ & $1.69 \times 10^{-5}$ & $1.58 \times 10^{-5}$ & $1.51 \times 10^{-5}$ & $1.69 \times 10^{-5}$ \\
\hline Resource depletion & $\mathrm{kg} \mathrm{Sb}$ eq & $1.93 \times 10^{-6}$ & $1.93 \times 10^{-6}$ & $1.97 \times 10^{-6}$ & $2.50 \times 10^{-6}$ & $2.30 \times 10^{-6}$ & $2.22 \times 10^{-6}$ & $2.45 \times 10^{-6}$ \\
\hline
\end{tabular}


Table 19 LCIA of $1 \mathrm{tkm}$ transported by electric trains in Belgium

\begin{tabular}{|c|c|c|c|c|c|c|c|c|}
\hline Impact category & Unit & 2006 & 2007 & 2008 & 2009 & 2010 & 2011 & 2012 \\
\hline hange & $\mathrm{CO}_{2} \mathrm{eq}$ & 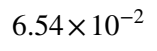 & $6.44 \times 10^{-2}$ & $6.77 \times 10^{-2}$ & $7.50 \times 10^{-2}$ & $6.38 \times 10^{-2}$ & $5.77 \times 10^{-2}$ & $6.12 \times 10^{-2}$ \\
\hline Ozone depletion & kg CFC-11 eq & $1.37 \times 10^{-8}$ & $1.33 \times 10^{-8}$ & $1.36 \times 10^{-8}$ & $1.39 \times 10^{-8}$ & $1.15 \times 10^{-8}$ & $1.23 \times 10^{-8}$ & $1.16 \times 10^{-8}$ \\
\hline Particulate matter & $\mathrm{kg} \mathrm{PM}_{2.5} \mathrm{eq}$ & $2.64 \times 10^{-5}$ & $2.62 \times 10^{-5}$ & $2.64 \times 10^{-5}$ & $3.21 \times 10^{-5}$ & $2.85 \times 10^{-5}$ & $2.77 \times 10^{-5}$ & $3.17 \times 10^{-5}$ \\
\hline Ionizing radiation $\mathrm{HH}$ & $\mathrm{kBq} \mathrm{U} 235 \mathrm{eq}$ & $8.86 \times 10^{-2}$ & $8.55 \times 10^{-2}$ & $8.65 \times 10^{-2}$ & $8.34 \times 10^{-2}$ & $6.61 \times 10^{-2}$ & $7.68 \times 10^{-2}$ & $6.67 \times 10^{-2}$ \\
\hline Photochemical & kg NMVOC eq & $1.60 \times 10^{-4}$ & $1.59 \times 10^{-4}$ & $1.63 \times 10^{-4}$ & $1.88 \times 10^{-4}$ & $1.65 \times 10^{-4}$ & $1.56 \times 10^{-4}$ & $1.78 \times 10^{-4}$ \\
\hline Aci & molc $\mathrm{H}^{+}$eq & $2.57 \times 10^{-4}$ & $2.54 \times 10^{-4}$ & $2.58 \times 10^{-4}$ & $3.03 \times 10^{-4}$ & $2.66 \times 10^{-4}$ & $2.53 \times 10^{-4}$ & $2.74 \times 10^{-4}$ \\
\hline Ter & mol & $5.48 \times 10^{-4}$ & $5.43 \times 10^{-4}$ & $5.60 \times 10^{-4}$ & $6.41 \times 10^{-4}$ & $5.58 \times 10^{-4}$ & $5.27 \times 10^{-4}$ & $5.62 \times 10^{-4}$ \\
\hline Fre & $\mathrm{k}$ & $1.73 \times 10^{-5}$ & $1.66 \times 10^{-5}$ & $1.74 \times 10^{-5}$ & $1.93 \times 10^{-5}$ & $1.72 \times 10^{-5}$ & $1.64 \times 10^{-5}$ & $2.00 \times 10^{-5}$ \\
\hline Resource depletion & $\mathrm{kg} \mathrm{Sb}$ eq & $2.18 \times 10^{-6}$ & $2.16 \times 10^{-6}$ & $2.19 \times 10^{-6}$ & $2.53 \times 10^{-6}$ & $2.24 \times 10^{-6}$ & $2.26 \times 10^{-6}$ & $2.32 \times 10^{-6}$ \\
\hline
\end{tabular}

Table 20 provides the results obtained in the LCIA of tkm tonne-kilometre of freight transported by rail in Belgium using the Belgian traction mix from 2006 to 2012, the average LCIA of Belgium taking as reference the period from 2006 to 2012 and the reference values of the process from Ecoinvent v3 "Transport, freight train $\{B E\} \mid$ processing I Alloc Rec, U”. The year 2009 presents the maximum impact in six indicators because this year presents a high energy consumption. There are no significant differences in terms of impact among the years 2006, 2007 and 2008. However, the year 2006 presents the maximum impact due to the higher exhaust emissions produced by the diesel traction in the indicators photochemical ozone formation and terrestrial eutrophication. By comparing the environmental impacts of the average rail freight transport (from 2006 to 2012) with the values from Ecoinvent v3, our results for Belgium show a higher impact in all the indicators.

\section{Discussion}

\section{Environmental impact assessment of rail freight transport in Belgium}

Figure 4 presents the contribution of the life cycle stages to the different environmental impact indicators, resulting from the LCIA of $1 \mathrm{tkm}$ of freight transported by different modes of rail freight transport in Belgium in the year 2012 (see the absolute values in Tables 18, 19 and 20): diesel trains, electric trains and rail freight transport considering the Belgian traction mix of 2012 (i.e. $86.3 \%$ of electric trains and $13.7 \%$ of diesel trains).

For diesel trains, exhaust emissions make the transport operation stage the most important contributor in the indicators climate change, particulate matter, photochemical ozone formation, acidification and terrestrial eutrophication. The use of biodiesel instead of conventional diesel presents benefits in terms of $\mathrm{CO}_{2}$ emissions and therefore could reduce the impact on climate change for diesel trains. However, the environmental impacts could be transferred from the transport operation stage to the agricultural field depending on what kind of feedstock and technology is used to produce the biodiesel.

For the indicator particulate matter, the exhaust emissions from diesel locomotives of primary particulate matter $\left(\mathrm{PM}_{2.5}\right)$ and the secondary particulate precursors $\mathrm{NO}_{\mathrm{X}}$ and $\mathrm{SO}_{2}$ during the transport operation are the main source of impact. Moreover, the exhaust emissions of $\mathrm{NO}_{\mathrm{X}}$ and NMVOC are the main contributor in the indicator photochemical ozone formation. This is because the $\mathrm{NO}_{\mathrm{X}}$ and NMVOC through photochemical reaction act as precursors of tropospheric ozone. Furthermore, the exhaust emissions of $\mathrm{NO}_{\mathrm{X}}$ are the main source of impact in the indicators acidification ( $\mathrm{SO}_{2}$ emissions also have a great influence) and terrestrial eutrophication. For the indicator ozone depletion, the main contributor of the impact in diesel trains is the emissions of bromotrifluoromethane $\left(\mathrm{CBrF}_{3}\right.$ or halon 1301) to air during the petroleum refinery operation. This gas contributes to the depletion of the stratospheric ozone layer, which absorbs most of the solar ultraviolet radiation.

For electric trains, the production of electricity is the most impacting stage in the indicators climate change, ozone depletion and ionizing radiation. The natural gas and coal power plants are important contributors to climate change (respectively contributing to $22.7 \%$ and $10.7 \%$ of the total impact of electric trains). Note that the natural gas and coal power plants represent the $22.2 \%$ and $5 \%$ of the electricity supply mix in Belgium in 2012, respectively. For the indicator ozone depletion, nuclear power is the main contributor due to the use of refrigerant gases in the uranium enrichment. For the indicator ionizing radiation (damage to human health), the nuclear power represents the $76 \%$ of the total impact of electric trains in this indicator.

Moreover, the electricity generation is an important contributor in the indicator freshwater eutrophication due to the hard coal and lignite mining. The hard coal and lignite power plants were responsible for $42 \%$ of the total electricity supply mix in Germany in the year 2012, and this, together that 




Germany was the main exporter of electricity to The Netherlands (24.4\%) and Luxembourg (65.3\%), which in turn were the exporting countries of electricity to Belgium (9.6\% from The Netherlands and $1.7 \%$ from Luxembourg), results in a higher impact in the indicator freshwater eutrophication of electric trains. Moreover, as noted above, the coal power plants contributed $5 \%$ of the total electricity supply mix in the year 2012.

The railway infrastructure construction is the main contributor in both indicators freshwater eutrophication due to the pollution from the production of primary copper and steel and resource depletion due to the consumption of materials such as gravel, steel and copper. Furthermore, the impact generated by the railway infrastructure construction is important in the indicator particulate matter due to the emissions of particles during the steel and gravel production and transport during the dismantling of the infrastructure. The railway infrastructure maintenance presents an important impact in the indicators ozone depletion, freshwater eutrophication and resource depletion as a result of the use of herbicides for weed control.

\section{Environmental impact assessment of rail freight transport using different electricity supply mix}

As mentioned above, the environmental impacts of electric trains depend on the electricity supply mix used; thus, their environmental performance differs according to the energy split of the country in which the train is located. In order to determine how the electricity supply mix affects the environmental impact of electric trains when they run through different countries in Europe, our study uses the electricity supply mix of Belgium, Germany, France, Italy, The Netherlands, Luxembourg and Poland corresponding to 2012 (Table 21) according to Eurostat data (Eurostat statistics 2017). The electricity supply mix for every country has been calculated using the domestic production of the different countries and exports and imports of electricity. The same methodology used to model the Belgian electricity supply mix has been employed for the other countries.

The purpose of the comparison is to understand how the electricity supply mix affects the environmental impact of electric trains when they cross the border between countries. Thus, for the railway infrastructure process and demand of the different countries, we have used the railway infrastructure process and demand from the Ecoinvent v3 database. However, since we assume that the train is the same, the processes connected with the rolling stock and transport operation with the exception of the electricity supplied remain unchanged.

Figure 5 compares the results obtained in the LCIA of $1 \mathrm{tkm}$ of freight transported by different modes of rail freight transport in Belgium (rail freight transport considering the 




Fig. 4 LCIA of $1 \mathrm{tkm}$ of rail freight transport using diesel traction, electric traction and the Belgian traction mix of 2012

Belgian traction mix of 2012, diesel trains and electric trains) and electric trains in Germany, France, Italy, The Netherlands, Luxembourg and Poland corresponding to the year 2012. An internal normalization of the LCIA results has been performed. Thereby, the results of the different environmental impact indicators have been divided by the maximum score of each indicator, allowing the comparison of the different alternatives of rail freight transport and facilitating the understanding of the results. Thus, the lowest and highest values of an indicator correspond to the alternative with minor and major impact, respectively.

Diesel trains present the highest score in the indicators photochemical ozone formation and terrestrial eutrophication due to the exhaust emissions (especially $\mathrm{NO}_{\mathrm{X}}$ and NMVOC direct emissions) produced in the diesel locomotives during the transport operation. Hence, a key factor to consider for improving the environmental performance of diesel locomotives is to upgrade their emission engine technology, the implementation of which might be hindered by the longer lifespan of locomotives. Moreover, diesel trains show the maximum impact in the indicator ozone depletion due to the pollutant emissions to air during the petroleum refinery operation. Furthermore, diesel trains present the highest score in the indicator resource depletion, but with a similar value than the Belgian electric trains and Belgian traction mix as a result of the similar demand of gravel, steel and copper for the construction of the railway infrastructure and the steel demand for the manufacturing and rolling stock. Note that for Belgium, a comprehensive inventory of the railway infrastructure has been carried out. On the contrary, for the other countries the railway infrastructure process and demand has been directly retrieved from the Ecoinvent v3 database. As a consequence, the material demand and environmental impact of the infrastructure are higher for Belgium than for the other countries.

Electric trains using the electricity supply mix of Poland present the highest score in the indicators climate change, particulate matter, acidification and freshwater eutrophication due to the use of a $49.2 \%$ of hard coal and $32 \%$ of lignite in the electricity generation in Poland. Thereby, the large emissions from coal power plants of GHG have a great impact on climate change; $\mathrm{SO}_{2}$ and particles emissions affect the indicator particulate matter; and the $\mathrm{SO}_{2}$ and $\mathrm{NO}_{\mathrm{X}}$ emissions affect the indicator acidification. For the indicator freshwater eutrophication, the main impact is produced in the lignite mining. 
Table 21 Electricity supply mix of Belgium $\{\mathrm{BE}\}$, Germany $\{\mathrm{DE}\}$, France $\{\mathrm{FR}\}$, Italy $\{$ IT $\}$, Luxembourg $\{$ LU $\}$, The Netherlands $\{\mathrm{NL}\}$ and Poland $\{P L\}$ in the year 2012. Sources: Eurostat statistics (2017) and Weidema et al. (2013)

\begin{tabular}{|c|c|c|c|c|c|c|c|}
\hline Energy source $(\%)$ & $\{\mathrm{BE}\}$ & $\{\mathrm{DE}\}$ & $\{\mathrm{FR}\}$ & $\{\mathrm{IT}\}$ & $\{N L\}$ & $\{L U\}$ & $\{\mathrm{PL}\}$ \\
\hline Hard coal & 4.99 & 18.81 & 2.84 & 10.67 & 14.19 & - & 49.23 \\
\hline Lignite & - & 23.22 & - & - & - & - & 32.03 \\
\hline Hydro, pumped storage & 1.41 & 1.02 & 0.90 & 0.66 & - & 5.21 & 0.28 \\
\hline Hydro, run-of-river & 1.79 & 3.86 & 9.72 & 5.10 & 0.09 & 5.65 & 1.61 \\
\hline Hydro, reservoir, non-alpine region & - & 0.76 & - & - & - & - & - \\
\hline Hydro, reservoir, alpine region & - & - & 1.86 & 9.07 & - & - & - \\
\hline Natural gas & 22.18 & 12.69 & 2.66 & 42.85 & 38.58 & 11.38 & 1.86 \\
\hline Nuclear, pressure water reactor & 41.88 & 12.69 & 75.42 & - & 3.24 & - & - \\
\hline Nuclear, boiling water reactor & - & 3.44 & - & - & - & - & - \\
\hline Oil & 0.37 & 1.39 & 0.71 & 7.81 & 1.26 & & 1.36 \\
\hline Wind, $<1 \mathrm{MW}$ turbine, onshore & 0.09 & 1.4 & 0.21 & 1.52 & 1.10 & 0.09 & 0.07 \\
\hline Wind, $>3 \mathrm{MW}$ turbine, onshore & 0.29 & 0.75 & 0.05 & 0.28 & 0.14 & - & 0.51 \\
\hline Wind, 1-3 MW turbine, offshore & 0.09 & 0.02 & - & - & 0.46 & - & - \\
\hline Wind, 1-3 MW turbine, onshore & 2.47 & 6.47 & 2.35 & 2.63 & 1.81 & 0.29 & 2.54 \\
\hline Geothermal & - & 0.00 & - & 1.74 & - & - & - \\
\hline Co-generation, biogas & 0.43 & 1.64 & 0.08 & 0.41 & 0.71 & 0.21 & 0.15 \\
\hline Co-generation, wood chips & 2.24 & 1.35 & 0.18 & 0.68 & 1.58 & - & 1.88 \\
\hline Treatment of blast furnace gas & 1.45 & 1.11 & 0.36 & 0.97 & 1.87 & - & 0.31 \\
\hline Treatment of coal gas & 0.06 & 0.32 & 0.11 & 0.41 & 0.19 & - & 0.98 \\
\hline Import from Belgium & - & - & 0.49 & - & 4.00 & 11.91 & - \\
\hline Import from France & 8.96 & 2.59 & - & 4.21 & 0.00 & 0.00 & - \\
\hline Import from Luxembourg & 1.67 & 0.00 & - & - & - & - & - \\
\hline Import from The Netherlands & 9.63 & 0.15 & - & - & - & - & - \\
\hline Import from Germany & - & - & 0.22 & - & 24.39 & 65.26 & 4.44 \\
\hline Import from Switzerland & - & 0.74 & 0.71 & 8.47 & - & - & - \\
\hline Import from Italy & - & - & 0.25 & - & - & - & - \\
\hline Import from Poland & - & 0.03 & - & - & - & - & - \\
\hline Import from Austria & - & 1.61 & - & 0.38 & - & - & - \\
\hline Import from Czech Republic & - & 1.65 & - & - & - & - & 0.06 \\
\hline Import from Sweden & - & 0.57 & - & - & - & - & 1.96 \\
\hline Import from UK & - & - & 0.25 & - & 0.28 & - & - \\
\hline Import from Denmark & - & 1.73 & - & - & - & - & - \\
\hline Import from Greece & - & - & - & 0.85 & - & - & - \\
\hline Import from Slovenia & - & - & - & 1.29 & - & - & - \\
\hline Import from Spain & - & - & 0.63 & - & - & - & - \\
\hline Import from Norway & - & - & - & - & 6.10 & - & - \\
\hline Import from Ukraine & - & - & - & - & - & - & 0.74 \\
\hline
\end{tabular}

As shown in Fig. 5, an electric train using the electricity supply mix of Poland has almost twice the impact on climate change than a diesel train in Belgium. This highlights the importance of the electricity source that is used in electric trains and is in accordance with the conclusions of Banar and Özdemir (2015) on improving the environmental performance of rail transport by using cleaner electricity. Therefore, a greater use of fossil energy in the electricity generation can produce that rail freight transport moved with electricity to be more polluting for climate change than rail freight transport moved with fossil energies such as diesel. It must be borne in mind that the use of electric trains leads to a reduction in local air pollution $\left(\mathrm{NO}_{\mathrm{X}}\right.$, particles, NMVOC and $\mathrm{SO}_{2}$ for example). Thereby, the use of electric trains avoids the population exposure to air pollutants emitted at ground level by diesel trains in highly populated areas.

Electric trains using the electricity supply mix of France show the maximum impact in the indicator ionizing radiation (damage to human health) due to the use of a $75.4 \%$ of nuclear power in the electricity production in France in 2012. Since the use of nuclear power in the electricity production is the determining factor in this indicator, the Belgian electric trains and the Belgian traction mix (with an $86.3 \%$ of electric trains) are the second and third with a 

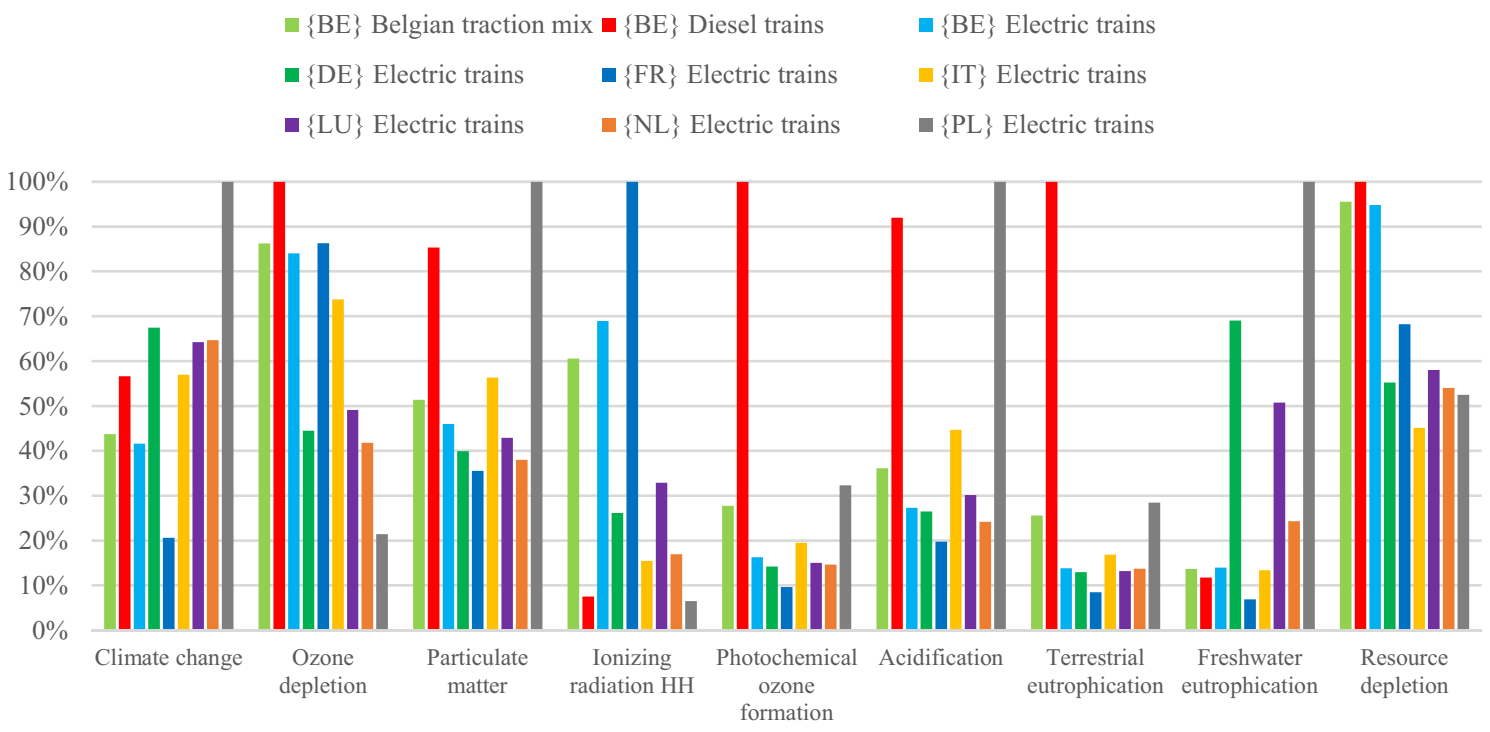

Fig. 5 LCIA of $1 \mathrm{tkm}$ transported by rail freight transport in Belgium $\{\mathrm{BE}\}$, Germany $\{\mathrm{DE}\}$, France $\{\mathrm{FR}\}$, Italy $\{$ IT $\}$, Luxembourg $\{\mathrm{LU}\}$, The Netherlands $\{$ NL $\}$ and Poland $\{P L\}$ in the year 2012

higher impact, respectively. The nuclear power plants were responsible for $41.9 \%$ of the total electricity supply mix in Belgium in 2012. Note that nuclear fission does not generate air emissions such as GHGs that affect climate change, but instead it produces nuclear wastes with a high potential impact on human health and ecosystems.

\section{Conclusion}

There exists a current trend towards a better understanding of the environmental aspects of transport from a life cycle perspective. Thereby, an increase in the number of studies using the LCA approach to study the environmental impacts of transport has taken place in recent times. This interest has increased as the LCA methodology has established itself as an effective tool to assess the environmental impacts of transport, and most importantly, to find ways to enhance its environmental impact. With this in mind, this paper analyses the environmental performance of rail freight transport in Belgium using a life cycle approach and regarding different environmental impact indicators. This study includes diesel trains, electric trains using the electricity supply mix in Belgium and other European countries and rail freight transport considering the Belgian traction. As a result of the LCA perspective, the connections between the energy and the transport sector have been analysed. Hence, it has been studied how the production of electricity is a major hot spot to improve the environmental performance of electric trains.

In view of the results obtained in our study, the electricity supply mix contributes significantly to the environmental performance of rail freight transport when using electric traction. Thus, as the use of electric trains increases in future and has a higher share of the total inland freight transport, the energy split for the electricity generation will be more important in the environmental impacts of goods transport. Since the use of electric trains becomes especially interesting when they are powered by sustainable electricity, the liberalization of the energy supplier market for the rail freight transport companies could be seen as an opportunity to improve the electric supply mix of electric trains. Rail freight transport operators could commit to clean electricity as a competitive factor. However, this could also have a negative effect, since companies could opt for cheaper energies such as nuclear energy or coal.

On the basis of the results obtained in the LCIA of rail freight transport in the year 2012, electric trains in Belgium show a better environmental performance than diesel trains. On the one hand, the use of electric trains rather than diesel trains represents a reduction of $26 \%$ of environmental impact on climate change, $16 \%$ on ozone depletion, $46 \%$ on particulate matter, $84 \%$ on photochemical ozone formation, $70 \%$ on acidification, $86 \%$ on terrestrial eutrophication and $5 \%$ on resource depletion. On the other hand, the use of electric trains represents an increase of $89 \%$ of impact on the indicator ionizing radiation (damage to human health) and $16 \%$ on freshwater eutrophication with regard to diesel trains. Furthermore, electric trains are more energy efficient than diesel trains and the use of electric locomotives rather than diesel locomotives enables one to transport heavier loads. Therefore, the increased use of electric trains represents an opportunity to attain a more environmentally and energyefficient rail freight transport system. 
Due to a lack of available data for recent years, the environmental impact of rail freight transport has been analysed in the period from 2006 to 2012. Therefore, this implies that this study does not account for recent changes such as variations in the rail freight traction share or electricity mix used by electric trains. However, a natural extension of this paper would be to develop a similar study for other countries. The methodology presented in this paper could be directly reused for the case of other geographical cases, possibly by making only some specific adaptations.

Acknowledgements The research underlying these results has been financed by the Belgian Science Policy under Contract No. [BR/132/ A4/BRAIN-TRAINS]. We thank Infrabel for assistance with data collection.

\section{References}

Banar M, Özdemir A (2015) An evaluation of railway passenger transport in Turkey using life cycle assessment and life cycle cost methods. Transp Res Part D 41:88-105

Barton K, Carlson R, Fracchia, M, Ghilardi, G, Hård, P, Kral, U, Leitao, N, Oberhauser, A, Steckler, P, Uppenberg, S (2010) D14 Suggestions for a process model for chosen components. In: InfraGuidER

Bilgili L, Kuzu SL, Çetinkaya AY, Kumar P (2019) Evaluation of railway versus highway emissions using LCA approach between the two cities of Middle Anatolia. Sustain Cities Soc 49:101635

Bolin CA, Smith ST (2013) Life cycle assessment of creosote-treated wooden railroad crossties in the US with comparisons to concrete and plastic composite railroad crossties. J Transp Technol 3:149-161

British Standards (2001) Railway applications-Track-Wood sleepers and bearers. The European Standard EN 13145:2001 has the status of a British Standard, BSi

Bueno G, Hoyos D, Capellán-Pérez I (2017) Evaluating the environmental performance of the high speed rail project in the Basque Country, Spain. Res Transp Econ 62:44-56

Chester M, Horvath A (2009) Environmental assessment of passenger transportation should include infrastructure and supply chains. Environ Res Lett 4:024008

Chester M, Horvath A (2010) Life-cycle assessment of high-speed rail: the case of California. Environ Res Lett 5:014003

De Bortoli A, Bouhaya L, Feraille A (2020) A life cycle model for high-speed rail infrastructure: environmental inventories and assessment of the Tours-Bordeaux railway in France. Int J Life Cycle Assess 25:814-830

Douglas H, Roberts C, Hillmansen S, Schmid F (2015) An assessment of available measures to reduce traction energy use in railway networks. Energy Convers Manag 106:1149-1165

EcoTransIT (2008) EcoTransIT: ecological transport information tool environmental. Methodology and data. ifeu - Institut für Energieund Umweltforschung Heidelberg GmbH, Heidelberg

European Commission (2011) White Paper on transport. Roadmap to a single European transport area-Towards a competitive and resource-efficient transport system. Directorate-General for Mobility and Transport

European Commission-Joint Research Centre-Institute for Environment and Sustainability (2010) International reference life cycle data system (ILCD) handbook—general guide for life cycle assessment—detailed guidance. Luxembourg
Eurostat Statistics (2017) Extracted on 17/08/2017. http://ec.europa.eu/ eurostat

Facanha C, Horvath A (2006) Environmental assessment of freight transportation in the U.S. Int J Life Cycle Assess 11(4):229-239

Facanha C, Horvath A (2007) Evaluation of life-cycle air emission factor of freight transportation. Environ Sci Technol 41(20):7138-7144

Fries N, Hellweg S (2014) LCA of land-based freight transportation: facilitating practical application and including accidents in LCIA. Int J Life Cycle Assess 19:546-557

Frischknecht, R, Jungbluth, N, Althaus, HJ, Doka, G, Dones, R, Heck, T, Hellweg, S, Hischier, R, Nemecek, T, Rebitzer, G, Spielmann, M, Wernet, G (2007) Overview and methodology. Ecoinvent report No. 1. Swiss Centre for Life Cycle Inventories, Dübendorf, Switzerland

Gleave, SD, Dionori, F, Casullo, L, Ellis, S, Ranghetti, D, Bablinski, K, Vollath, C, Soutra, C (2015) Freight on road: why EU shippers prefer truck to train. Directorate General for Internal Policies, Policy Department B: Structural and Cohesion Policies, Transport and Tourism, European Parliament's Committee on Transport and Tourism

IBGE (2011) Les données de l'IBGE : Interface santé et environnement. 38. Créosote. Bruxelles Environnement-Observatoire des données de l'environnement

Infrabel (2007) Fascicule 52. Prescriptions techniques relatives aux entreprises. Travaux de voie

Infrabel (2011) Spécification technique H-1. Traverses en bois non traitées et supports en bois (pièces de bois) non traités pour appareil de voie

Infrabel (2014) Network statement. Infrabel, Belgium

Infrabel (2016) Information collected from Infrabel employees through the use of questionnaires

ISO (2006a) ISO 14040: Management environnemental-Analyse du cycle de vie-Principes et cadre. International Standardization Organization

ISO (2006b) ISO 14044: Management environnemental-Analyse du cycle de vie-Exigences et lignes directrices. International Standardization Organization

Jones H, Moura F, Domingos T (2017) Life cycle assessment of high-speed rail: a case study in Portugal. Int J Life Cycle Assess 22:410-422

Kiani M, Parry T, Ceney H (2008) Environmental life-cycle assessment of railway track beds. Eng Sustain 161(ES2):135-142

Krezo S, Mirza O, He Y, Makim P, Kaewunruen S (2016) Field investigation and parametric study of greenhouse gas emissions from railway plain-line renewals. Transp Res Part D 42:77-90

Künniger, T, Richter, K (1998) Comparative life cycle assessment of Swiss railroad sleepers. In: EMPA Dübendorf, The International research group on wood preservation, 29th annual meeting, Maastricht, The Netherlands

Lin J, Cheng S, Li H, Yang D, Lin T (2019) Environmental footprints of high-speed railway construction in china: a case study of the Beijing-Tianjin Line. Int J Environ Res Public Health 17(1):105

Merchan, AL, Belboom, S, Léonard, A (2017) Life cycle assessment of freight transport in Belgium. In: Proceedings of the BIVECGIBET transport research days, Liège, Belgium

Merchan AL, Léonard A, Limbourg S, Mostert M (2019) Life cycle externalities versus external costs: the case of inland freight transport in Belgium. Transp Res Part D 67:576-595

Messagie M, van Lier T, Rangajaru S, van Meirlo J (2014) Energieintensiteit van personen- en goederenvervoer, studie uitvoerd in opdracht van de Vlaamse Milieumaatschappij. Vrije Universiteit Brussel, MIRA

Milford RL, Allwood JM (2010) Assessing the $\mathrm{CO}_{2}$ impact of current and future rail track in the UK. Transp Res Part D 15:61-72

PREFER (2006) Traverse Monobloc Précontrainte M41. www.prefer.be 
Schmied M, Mottschall M (2013) Treibhausgasemissionen durch die Schieneninfrastruktur und Schienen-fahrzeuge in Deutschland. Öko-Institut e.V. - Büro, Berlin

Service Public Wallonie (2012) Le transport ferroviaire : un atout structurant pour la Wallonie. Projet de Plan de développement de la desserte ferroviaire en Wallonie pour la période 2013-2025

SNCB (2009) Rapport de développement durable 2008

SNCB (2013) Entreprise durable, le groupe SNCB sur la voie du développement durable

SNCB (2015) Entreprise durable, le groupe SNCB sur la voie du développement durable

Spielmann M, Scholz RW (2005) Life cycle inventories of transport services. Background data for freight transport. Int J Life Cycle Assess 10(1):85-94

Spielmann, M, Bauer, C, Dones, R, Tuchschmid M (2007) Transport Services. Ecoinvent report No. 14. Swiss Centre for Life Cycle Inventories, Dübendorf, Switzerland

Statistics Belgium (2017) Extracted on 06/01/2017. http://statbel.fgov. be

Stripple H, Uppenberg S (2010) Life cycle assessment of railways and rail transport-application in environmental product declarations (EPDs) for the Bothnia Line. Swedish Environmental Research Institute, Stockholm

Troch F, Vanelslander T, Sys C, Laroche F, Merchan A, Mostert M, Stevens V, Tawfik C, Belboom S, Léonard A, Limbourg S, Verhoest K (2017) A road map for explorative scenario creation on Belgian rail freight transport development. Compet Regul Netw Ind 18:3-21

Tuchschmid, M, Knörr, W, Schacht, A, Mottschall, M, Schmied, M (2011) Carbon Footprint and environmental impact of railway infrastructure. Commissioned by International Union of Railways (UIC), IFEU-Institut Heidelberg and Öko-Institut e.V - Büro Berlin, Germany

Twisse, F, Scott, P (2012) EU fuel quality monitoring summary Report 2010. European Commission-DG Climate Action, United Kingdom
Ueda H, Tsujimura T, Takai H, Emoto M (1999) Fundamental investigation of LCA of cross tie. Q Rep Railw Tech Res Inst 40(4):210-2013

UIC (2010) International railways statistics. International Union of Railways (UIC), Paris

UIC (2013) SUWOS. Sustainable wooden railway sleepers. International Union of Railways (UIC), Paris

Van de Voorde, E, Vanelslander, T (2014) Development of rail freight in Europe: What regulation can and cannot do. Belgium case study, Centre on Regulation in Europe, Belgium

VMM (2008) Lozingen in de lucht 1990-2007. Vlaamse Milieumaatschappij

VMM (2009) Lozingen in de lucht 1990-2008. Vlaamse Milieumaatschappij

VMM (2010) Lozingen in de lucht 1990-2009. Vlaamse Milieumaatschappij

VMM (2012) Lozingen in de lucht 2000-2011. Vlaamse Milieumaatschappij

VMM (2013) Lozingen in de lucht 2000-2012. Vlaamse Milieumaatschappij

Von Rozycki C, Koeser H, Schwarz H (2003) Ecology profile of the German high-speed rail passenger transport system, ICE. Int J Life Cycle Assess 8(2):83-91

Weidema, BP, Bauer, C, Hischier, R, Mutel, C, Nemecek, T, Reinhard, J, Vadenbo, C, Wernet, G (2013) The ecoinvent database: overview and methodology, Data quality guideline for the ecoinvent database version 3 www.ecoinvent.org

Yue Y, Wang T, Liang S, Yang J, Hou P, Qu S, Zhou J, Jia X, Wang H, Xu M (2015) Life cycle assessment of high speed rail in China. Transp Res Part D 41:367-376

Publisher's Note Springer Nature remains neutral with regard to jurisdictional claims in published maps and institutional affiliations. 